\title{
LATE PRE-HISPANIC AND EARLY COLONIAL SIIVER PRODUCTION IN THE QUEBRADA DE TARAPACÁ, NORTHERN CHILE
}

\section{LA PRODUCCIÓN DE PLATA EN LOS PERIOODOS PREHISPÁNICO TARDÍOY COLONIAL TEMPRANO EN LA QUEBRADA DE TARAPACÁ, NORTE DE CHILE}

\author{
Colleen M. Zori * \& Peter Tropper* *
}

\begin{abstract}
Drawing on a survey of the Quebrada de Tarapacá in northern Chile and excavations at the Inka and Colonial administrative site of Tarapacá Viejo, we present archaeological evidence of small-scale purification of silver using lead. We argue that the use of techniques to refine silver-bearing ores most likely began in the Late Horizon (AD 1450-1532), when local metallurgists may have processed minerals from the nearby silver mines of Huantajaya as part of their labor tribute to the Inka state. Although the adoption of mercury amalgamation technologies introduced by Europeans allowed for large-scale refining of silver, lead purification techniques continued in use into the early Colonial Period (AD 1532-1700).
\end{abstract}

Key words: Inka, metallurgy, Huantajaya, silver, lead cupellation

Usando datos de una prospección en la Quebrada de Tarapacá del norte de Chile y excavaciones en el sitio administrativo inka y colonial de Tarapacá Viejo, presentamos evidencia arqueológica de la purificación de plata en pequeña escala usando plomo. Sugerimos que el uso de técnicas para refinar los minerales de plata se inició más probablemente en el Horizonte Tardío (1450-1532 DC), cuando los metalurgistas locales pudieron haber procesado plata de las minas de Huantajaya como parte de su tributo al estado Inka. Si bien la adopción de las tecnologías de amalgamación de mercurio introducidas por los europeos permitió la refinación en gran escala de los minerales de plata, el uso de técnicas de purificación con plomo continuó en el Período Colonial Temprano (1532-1700 DC).

Palabras clave: Inka, metalurgia, Huantajaya, plata, copelación con plomo

\section{INTRODUCTION}

The predominant model of Inka expansion into northern Chile centers on their desire to gain access to the abundant copper deposits of the region (Niemeyer \& Schiappacasse 1988; Castro 1992; Lynch \& Núñez 1994; Cornejo 1995; Núñez, L. 1999; Uribe 1999-2000; Uribe \& Carrasco 1999; Salazar 2002, 2008; Adán \& Uribe 2005). Curiously, less attention has been given to the extraction of silver in the late pre-Hispanic period, despite ethnohistoric accounts that the mines of Huantajaya surpassed those of Porco in their richness and were an important center for Inka silver extraction (Cobo 1979 [1653]; Pizarro 1986 [1571]). Colonial sources further relate that much of the wealth of Lucas Martínez Vegazo, the first encomendero of the Tarapacá region, derived from the silver mines of Huantajaya (Villalobos 1979; Trelles 1982; Núñez, P. 1984; Gavira 2005; Hidalgo 2009).

Although documentary sources suggest that early prospecting at Huantajaya focused on large and easily exploited lodes of native silver, the mines also contain veins of silver-bearing ores that would have required additional processing, including argentite $\left(\mathrm{Ag}_{2} \mathrm{~S}\right.$, a silver sulfide), chlorargyrite ( $\mathrm{AgCl}$, a silver chloride) and proustite $\left(\mathrm{Ag}_{3} \mathrm{AsS}_{3}\right.$, silver arsenic sulfide; Brown \& Craig 1994;

* Colleen Zori, Department of Anthropology, University of California, Los Angeles (UCLA), 375 Portola Plaza, 341 Haines Hall, Box 951553 , Los Angeles, CA 90095-1553, USA, email: colleen.zori@ucla.edu

** Peter Tropper, Institute of Mineralogy and Petrography, University of Innsbruck, Innrain 52, A-6020 Innsbruck, Austria, email: peter.tropper@uibk.ac.at 
Maksaev et al. 2007). Due to the chronic lack of water, fuel, and food at the mines themselves, on-site refining of silver-bearing ores would have been a challenge for both Late Horizon and Colonial miners. Sources from the late Colonial Period indicate that at least a portion of the silver ores were refined in the nearby transverse valleys and at the oasis of Pica, where water, trees for fuel, and agricultural resources were more plentiful (Bollaert 1851; Brown \& Craig 1994; Gavira 2005; Mukerjee 2008; Hidalgo 2009).

We present an analysis of archaeometallurgical materials characteristic of the small-scale processing of silver from the Quebrada de Tarapacá, located approximately $60 \mathrm{~km}$ northeast of the Huantajaya mines (figs. 1 and 2). The artifacts were recovered from several smelting sites identified in a pedestrian survey of $18 \mathrm{~km}^{2}$ of the lower Quebrada de Tarapacá and from excavations at the site of Tarapacá Viejo (fig. 3). This multi-occupational settlement served as the administrative center of the lower portion of the valley in both the Late Horizon and Colonial Period until the site's abandonment in AD 1717 (Núñez, L. 1979; Núñez, P. 1984; Uribe et al. 2007; Zori 2011). Although it has not been possible to conclusively distinguish between late pre-Hispanic and early Colonial silver refining, we argue that the techniques used to purify silver-bearing ores were most likely introduced during the Late Horizon and used to process ores from Huantajaya for the Inka state. These techniques were then used into the historic period, even after the adoption of mercury amalgamation technologies that allowed for large-scale refining of silver ores.

We first outline the process of extracting silver using lead cupellation, and then discuss both ethnohistoric and archaeological evidence for the use of lead in the purification of silver in the Andes before the arrival of Europeans in the sixteenth century. We explore the historical connections between the mines of Huantajaya and the Quebrada de Tarapacá, where several different forms of silver refining have been documented for the later Colonial Period, and then provide archaeological evidence that silver purification using lead occurred in the Late Horizon and early Colonial Period. We suggest that some of the silver may have derived from Huantajaya, and further argue that the Inka claimed this metal as tribute. We likewise conclude that a central objective of the Inka state in the region was silver extraction, along with that of copper and possibly other minerals.

\section{THE PRODUCTION OF SILVER VIA LEAD CUPELLATION}

Although veins and bonanza deposits of native silver occur in the Andes, most silver exists in polymetallic ore deposits combined with other metals such as gold and copper (Lechtman 1976). Obtaining silver from these ores would have required additional processing, one form of which involves the use of lead.

At the smelting stage, ancient metallurgists used lead to add bulk to the metal fraction, thereby facilitating the separation of the silver metal from the slag and its formation as lead-silver bullion by the end of the smelt (Howe \& Petersen 1994; Schultze et al. 2009). Lead could be added to the furnace in the form of lead ore, lead metal $(\mathrm{Pb})$, litharge ( $\mathrm{PbO}$ or lead oxide), or lead-containing slag (Howe \& Petersen 1994; Gordon \& Knopf 2007). The resulting lead-silver bullion may also contain matte, which is a mixture of metal sulfides with minor amounts of silicates and traces of other base metals from the original ores.

Purification of lead-silver bullion takes place in several different stages-including an intermediate process known as scorification-that typically culminate in cupellation. In scorification, the lead-silver bullion is heated in an open ceramic vessel or on a flat ceramic surface in an oxygen-rich environment. Through reactions with quartz found in the clay of the ceramic vessel and/or other silicate minerals left over from the gangue, a portion of the lead oxidizes and forms lead silicate slag (Schultze et al. 2009). Other base metals present in the original minerals are trapped in the lead silicate slag as well, further purifying the lead-silver mixture. Scorification also results in the separation and removal of matte from the bullion. Purification in this manner thus eliminates a portion of the lead as well as some of the other impurities from the bullion, leaving the metal enriched in silver and ready for cupellation

In cupellation, the silver-enriched bullion is heated to a temperature of $900^{\circ} \mathrm{C}$ or higher in an oxidizing environment, causing the formation of litharge. Cupellation sometimes takes place in a hearth lined with bone ash or other calcareous material that absorbs the litharge as it forms, eventually leaving behind an unoxidized button of pure silver (Tylecote 1964). Litharge also collects oxides of any base metals still present in the lead-silver bullion. Cupellation can also be carried out in an open ceramic vessel, or cupel. If unlined with bone ash or other absorbent material, the silica in the clay of the ceramic vessel vitrifies when heated, blocking the absorption of the liquid metal oxides (Söderberg 2004). Because litharge is immiscible with the silver metal, 


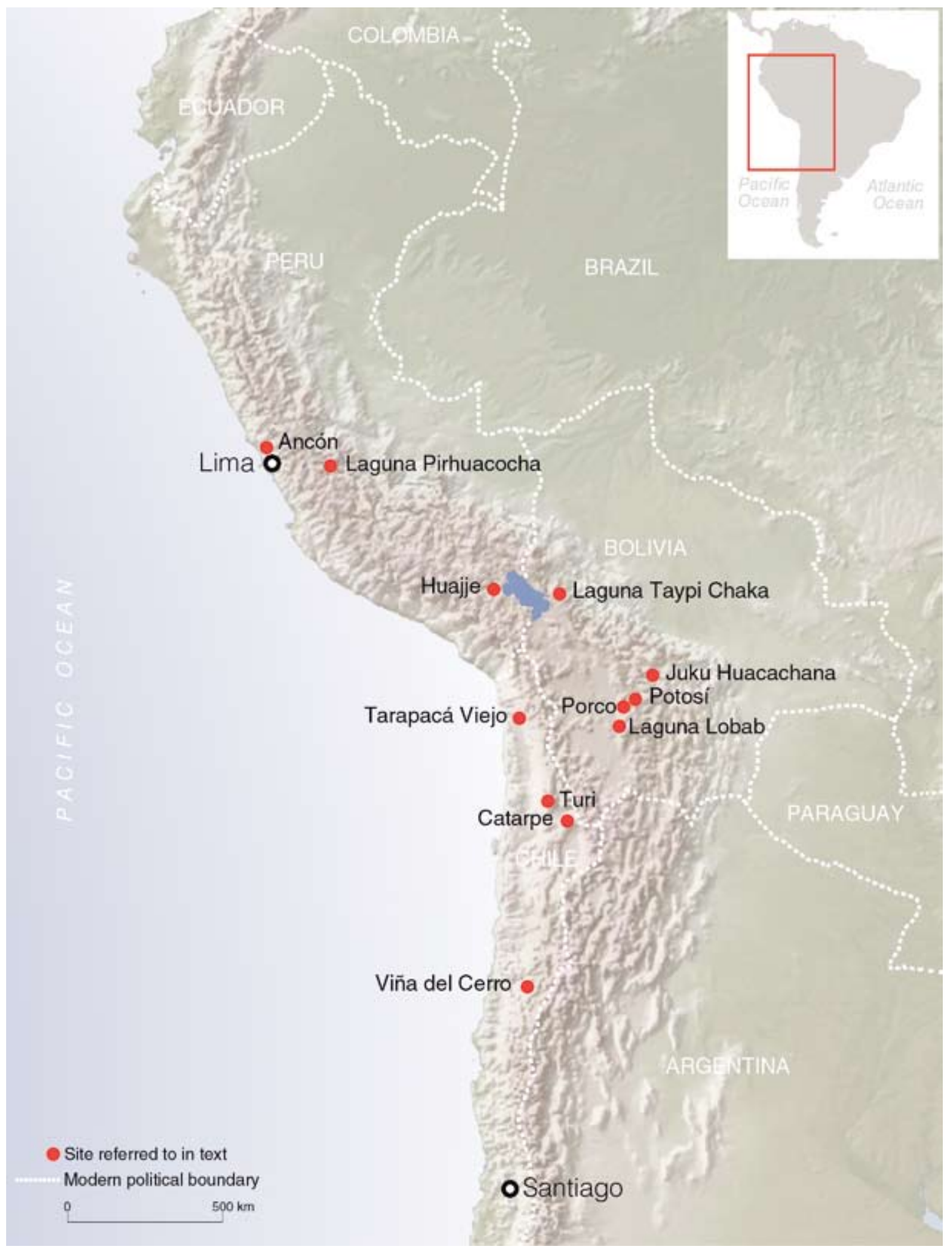

Figure 1. Sites mentioned in the text. Figura 1. Sitios mencionados en el texto 


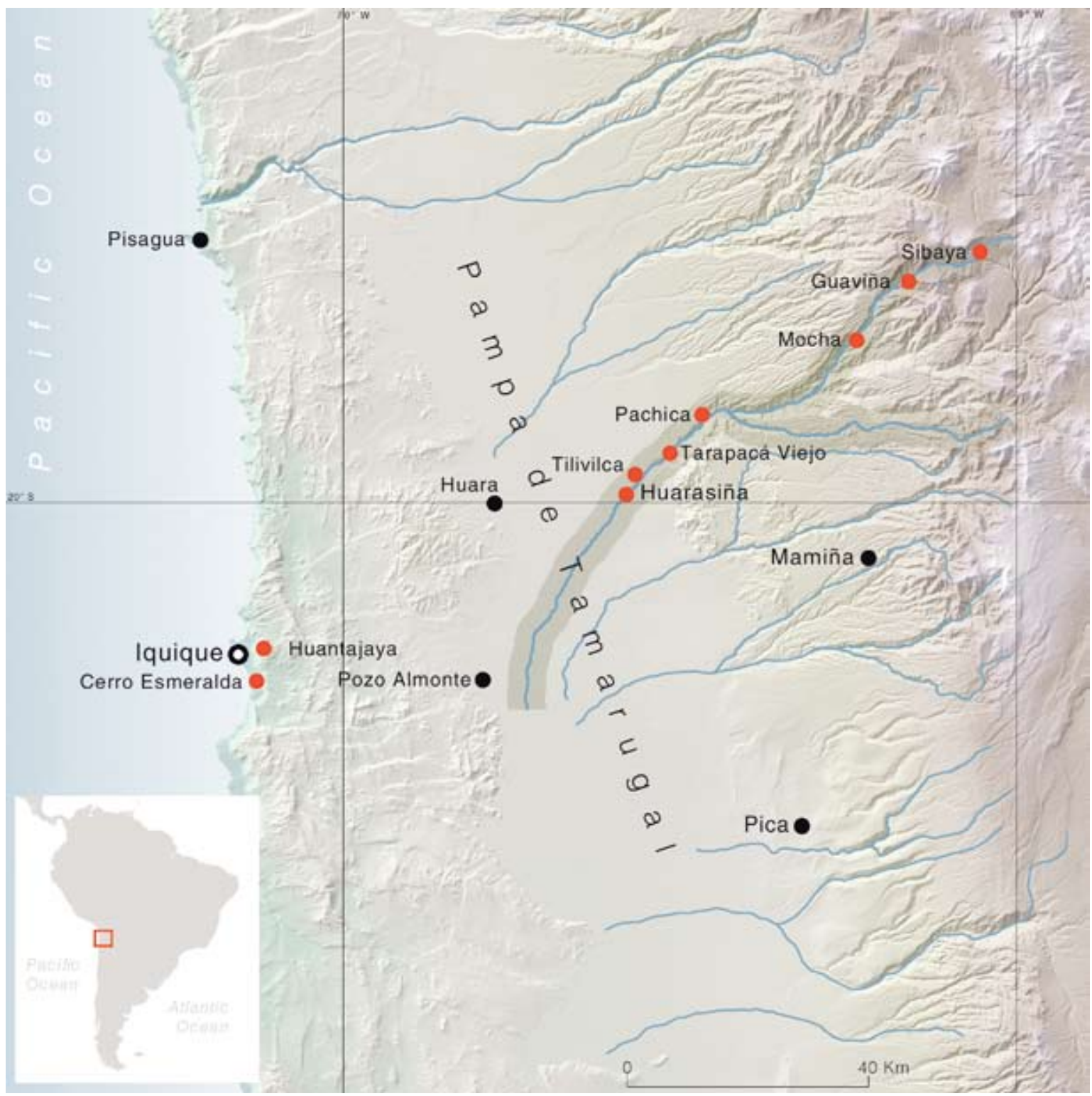

Figure 2. Tarapacá Region of northern Chile.

Figura 2. Región de Tarapacá en el norte de Chile.

it floats on top and can be skimmed off, gradually removing lead and other impurities and finally leaving behind pure silver (Tylecote 1964; Lechtman 1976).

\section{EVIDENCE OF SILVER PRODUCTION IN THE PREHISTORIC AND COLONIAL ANDES}

Almost four decades ago, Clair Patterson (1971) categorically rejected the idea that pre-Hispanic metallurgists in the Andes had developed the technique of purifying silver using lead. Insights from documentary sources and an increasingly convincing body of archaeological evidence, however, indicate that smelting of silver-bearing minerals with lead and the techniques of scorification and cupellation were relatively widespread in the Andes, even before the arrival of Europeans.

\section{Ethnohistoric sources for the silver production process}

Descriptions of indigenous techniques of silver production are primarily found in early historic sources 


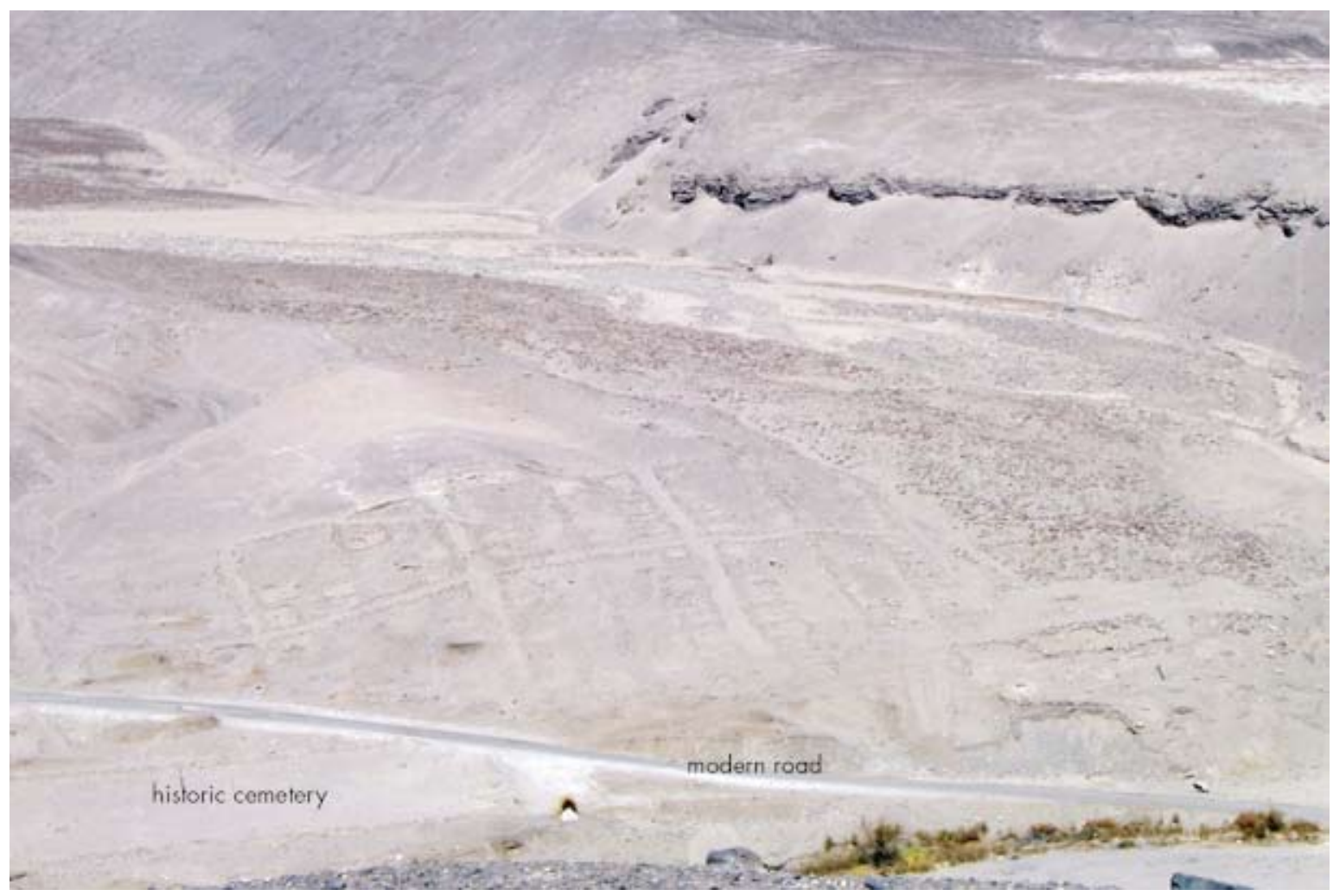

Figure 3. Tarapacá Viejo (photo by Rodrigo Riveros Strange).

Figura 3. Tarapacá Viejo (foto: Rodrigo Riveros Strange).

that derive from the Porco-Potosí region of modernday Bolivia (see fig. 1), the most important center of Colonial silver production in the New World. Capoche (1959 [1585]) describes a two-stage process consisting of smelting followed by a second purification stage, probably cupellation. High-grade silver minerals were first ground and then smelted with a mixture of soroche and/or asendrada. Soroche has been identified as galena, a lead sulfide ore that frequently contains small quantities of silver (see also Garcilaso de la Vega 1941-1943 [1609]; Petersen 1970; Lechtman 1976; Howe \& Petersen 1994; Acosta 2002 [1590]; Van Buren \& Mills 2005). Asendrada is litharge, or lead oxide, which is produced in the final cupellation stage of silver refining. When added to the smelting charge, both soroche and asendrada would have added lead to aid in the collection of the silver.

Both Acosta (2002 [1590]) and Garcilaso de la Vega (1941-1943 [1609]) specify that the smelting of the silver and lead ores and/or the silver ores and the litharge took place in clay furnaces powered by the wind, an indigenous form of smelting technology known as a huayra or buayrachina. ${ }^{1}$ Ethnohistoric sources suggest that huayras were relatively similar in form and physical attributes, but perhaps differed in their construction materials and whether they were fixed or portable (Barba 1923 [1640]; Garcilaso de la Vega 1941-1943 [1609]; Capoche 1959 [1585]; Cieza de Léon 1986 [1553]; Acosta 2002 [1590]; see reviews in Bargallo 1973; Oehm 1984; Van Buren \& Mills 2005). These sources generally describe furnaces that were columnar in shape, flaring at the top and somewhat narrower at the bottom, and perforated by numerous holes through which the wind would have blown to heat the charge (fig. 4). They were approximately $84 \mathrm{~cm}$, or one vara, in height. Many variants of this type of furnace likely existed both historically and prehistorically (see e. g., Petersen 1970; Niemeyer et al. 1984; Graffam et al. 1996; Raffino et al. 1996; González 2002; Van Buren \& Mills 2005), but the two most commonly described are a stationary or fixed furnace constructed of stones in a mud-mortar matrix, and a portable version with thinner walls made of clay. Historically, huayras were used to produce lead-silver bullion, although modern ethnographic examples demonstrate that huayras can also be used to produce pure lead metal that is subsequently used in the scorification and/or cupellation stages (Van Buren \& Mills 2005; Cohen et al. 2008). 
A

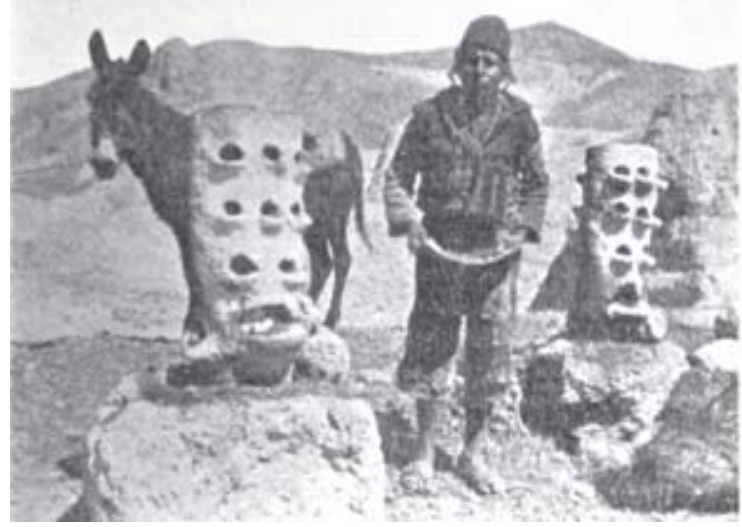

B

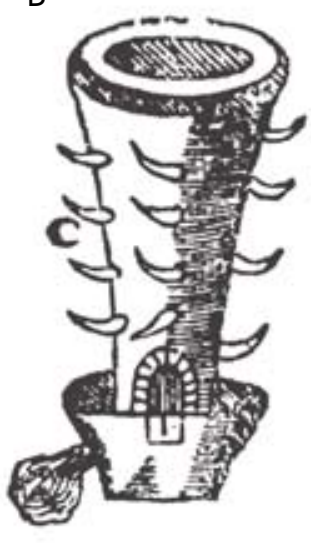

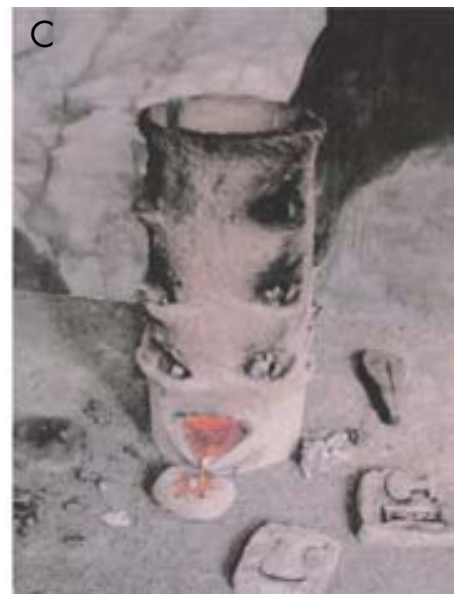

Figure 4. Ethnographic and ethnohistoric examples of huayras: A) unidentified metallurgist in Bolivia (Peele 1893: 9); B) drawing of a Colonial huayra by Alonso Barba (1923 [1640]: 199); C) reconstruction in the Museo Nacional de La Paz (photo by C. Zori).

Figura 4. Ejemplos etnográficos y etnobistóricos de huayras: A) metalurgista anónimo en Bolivia (Peele 1893: 9); B) dibujo de una huayra colonial realizado por Alonso Barba (1923 [1640]: 199); C) reconstrucción en el Museo Nacional de La Paz (foto: C. Zori).

The silver-containing lead bullion produced by indigenous metallurgists in the Colonial Period was subsequently subjected to further purification. Unfortunately, Capoche's description of the refining process is vague. He states only that after smelting, the silver-lead bullion was taken "to smelt and refine in their houses, in small ovens with a gentle flame," the products of which were pure silver and litharge (Capoche 1959 [1585]: 110; our translation). ${ }^{2}$ Garcilaso de la Vega (1941-1943 [1609]: Book IV, Ch. 15) is somewhat more specific, relating that the lead-silver bullion was subjected to a second and even third smelting (remelting?) carried out in houses, presumably of the metallurgists themselves, using blowpipes rather than the wind-driven buayras. Although the scorification and/or cupellation processes are not described per se, Lechtman (1976: 36) notes that "he implies that these final steps were carried out in vessels of some kind with the air for the fire being provided by people blowing into copper blowpipes in order to purify the silver and get rid of the (waste) lead."

\section{Archaeological evidence of the silver refining process}

Archaeological evidence from the Andes confirms the prehistoric use of lead in the purification of silver, and sheds light on both the chronological development and geographic distribution of that technology (see fig. 1 for sites mentioned in text).

The earliest known evidence of silver production in the South Central Andes has been documented at the site of Huajje, located in the northwestern Lake Titicaca
Basin, where calibrated radiocarbon dates associated with the oldest metallurgical artifacts range between 40 BC-AD 240 (Schultze et al. 2009). Primary smelting of silver-bearing ores does not appear to have taken place at Huajje itself, as suggested by the absence of furnace fragments or smelting slags (Schultze et al. 2009). Instead, metallurgical activity focused on the purification of lead-silver bullion through scorification, as evidenced by ceramic crucible fragments whose interior faces were coated with lead silicate slag and litharge. Loose lead-silicate slag and several matte cakes were also recovered. Material evidence for cupellation was not found at Huajje, and the investigators propose that the silver-enriched metal may have been further purified elsewhere, perhaps under greater supervision by the Tiwanaku state (Schultze et al. 2009).

Evidence of silver purification in the form of numerous plano-convex lead-rich cakes has been recovered from the site of Ancón, located approximately $25 \mathrm{~km}$ north of Lima on the central coast of Peru (Lechtman 1976). Metallurgical remains at the site date from the Middle Horizon through the Late Horizon, although the precise chronological affiliation of the lead-rich cakes is unknown. Petrographic and X-ray diffraction (XRD) analyses indicate that the upper layers of the cakes contain globules of lead and bits of galena, while the remainder is comprised of litharge. Small prills of copper were also found throughout the cakes. The presence of galena suggests either that soroche was added to smelt a silver-rich ore or that an argentiferous galena was smelted in the first stage, while the copper droplets found in the cakes are a result of the collecting action of the lead oxides, removing the 
base metals present in the original ores. Because the cakes are almost pure litharge, they likely represent one of the final stages in the silver purification process (Lechtman 1976: 37). The shape of the cakes indicates that the process took place in a pre-shaped receptacle, such as a shallow bowl.

At the site of Juku Huachana, northeast of Potosí, Téreygeol and Castro (2008) document evidence for several stages in the silver refining process dating to the Late Intermediate Period and Late Horizon. They identified buayra fragments whose slagged interiors contained high levels of lead and silver, suggesting the production of lead-silver bullion. X-ray fluorescence (XRF) analysis of two bowl-shaped vessels used as crucibles demonstrated very high levels of lead in the slag on the interiors, indicating that scorification was carried out at Juku Huachana as well (Téreygeol \& Castro 2008: 25). Evidence for the cupellation stage was not recovered at the site.

Layers of lacustrine sediment provide an additional record of the pre-Hispanic use of lead cupellation, as well as an increase in the scale of silver production during the Late Horizon under the Inka. Smelting of lead ores and the use of lead in silver purification results in the volatilization of lead, silver, and other metals into the atmosphere and their subsequent deposition in the sediments of near-by lakes. Levels of these metals in the stratigraphic layers of a lakebed thus provide a record of the timing and intensity of a region's silver production. Cooke and colleagues (2008; see also Abbott \& Wolfe 2003) studied lacustrine sediments from three lakes arrayed along the north-south axis of the Andes: Laguna Pirhuacocha, located in the Morococha mining district of Junín province in central Peru; Laguna Taypi Chaka, located in the Lake Titicaca hydrological catchment basin approximately $25 \mathrm{~km}$ east of Tiwanaku; and Laguna Lobato, adjacent to the rich silver deposits of Potosí.

Analysis of sediments from Laguna Taypi Chaka demonstrated a significant increase in lead deposition beginning around $\mathrm{AD} 400$ and peaking at approximately AD 1040, dates closely correlated with the development and collapse of the Tiwanaku polity in the region (Cooke et al. 2008). Both Laguna Lobato and Laguna Pirhuacocha experienced increases in lead deposition above baseline ambient levels in the subsequent centuries (AD 1000-1400), and the authors suggest that metallurgists skilled in silver refining technology may have migrated out of the Titicaca Basin as a result of Tiwanaku's collapse, spreading the technique to other regions of the Andes (Cooke et al. 2008: 357). ${ }^{3}$ Although lead deposition gradually rose through the
Late Intermediate Period, all three lakes experienced significant increases after the respective regions were conquered and incorporated into the Inka empire. This is consistent with the expansion of local silver production to meet state demands (Abbott \& Wolfe 2003; Cooke et al. 2008).

\section{HUANTAJAYA AND THE QUEBRADA DE TARAPACA}

Cerro Huantajaya is located $11 \mathrm{~km}$ inland from the modern-day city of Iquique (see fig. 2). Although a more dubious version of its discovery recounts that the Huantajaya silver deposits were first identified by a Portuguese man travelling with Diego de Almagro in 1535 (Hidalgo 1985), it is generally accepted that silver mining there began in the pre-Hispanic period. Brown and Craig (1994) report the discovery of the skeletons of two prehistoric miners found trapped by a cave-in, but do not provide any additional data that would help date the finds. Ethnohistoric sources suggest that the local inhabitants were aware of the rich deposits of silver at the time of European contact, but initially concealed them from the Spaniards (Cobo 1979 [1653]). Cobo (1979 [1653]: Ch. 33) relates that a large vein or veins at Huantajaya were worked on behalf of the Inka using mit'a labor, and were considered the sacred property of the Sun. This is corroborated by a description of the mines by Pizarro (1986 [1571]: 189; our translation), who recounts that the encomendero Vegazo was "working in a cave where first they took out silver for the Inka" where there was "a vein that the Indians had tapped, that they said belonged to the Sun, two feet wide, all of fine silver."

Pizarro (1986 [1571]: 189) goes on to describe the large nuggets of silver that were characteristic of the rich albeit discontinuous veins of silver at Huantajaya: "[t]hey found some round papas [potatoes] as in the manner of truffles... potatoes of silver loose in the ground, with weights of two hundred pesos [a Spanish unit of weight for silver equivalent to 27 grams], and three hundred, and five hundred, and of an arroba [equivalent to $11.3 \mathrm{~kg}]$ and of two arrobas, and sometimes of a quintal [equivalent to $100 \mathrm{~kg}$ ]." Platt and colleagues (2006: 157, 158) suggest that these "papas" of silver were actually "mamas" revered by Andean peoples as sacred buacas (Albornoz 1989 [1581/1585]; Berthelot 1986; Cieza de León 1986 [1553]; Cobo 1990 [1653]: Ch. 33; Bouysse-Cassagne 2005, 2008), and that the Inka may have been particularly interested in controlling mines that produced such large nodules of gold or silver. Scholars have similarly 
argued that the richness and potentially sacred nature of the Huantajaya mines may account for why the Inka performed a capacocha ceremony at the nearby site of Cerro Esmeralda, which, at 905 m.a.s.l., is one of very few low-altitude sacrifices known in the Andes (Checura 1977; see fig. 2).

As early as 1543 , Vegazo had already hired prospectors to mine Huantajaya, with native inhabitants of the encomienda providing the necessary labor (Trelles 1982; Núñez 1984; Gavira 2005). Vegazo's mining operations continued until his death in 1567 , and then mention of the Huantajaya mines subsequently disappeared from historical records until they were "rediscovered" in the late seventeenth century (Bollaert 1851: 107; Brown \& Craig 1994; Gavira 2005). There was then a greater effort to systematically exploit the silver deposits, although lack of water at the site prevented the development of on-site facilities to process and smelt these minerals. Instead, most silver ore from Huantajaya was transported overland to the water-powered stamp mills of Potosí during the late Colonial Period (Brown \& Craig 1994).

The rest, however, was processed locally in the inland valleys, including the Quebrada de Tarapacá. Refining operations were carried out by several distinct groups of individuals operating on different scales in the late Colonial Period. In their account of mining at Huantajaya in the eighteenth century, Brown and Craig (1994: 314) mention that on Sundays after mass, indigenous and meztizo miners would use their free time to "[clean] and [pick] over the accumulated ore that was sent to Tarapacá, Pica or Guarasina [Huarasiña] for small-scale beneficiation and artisanal refining." Early nineteenth century documents indicate that somewhat larger quantities of silver ores were purified by Spanish metallurgists in Pica and the Pampa de Tamarugal using a technique of mercury amalgamation developed by Barba (1923 [1540]: Bk. 3) that was carried out in copper vessels (see Gavira 2005: 40). Concurrently, greater quantities of silver were processed using the "patio process" of mercury amalgamation at the azogueria of Tilivilca, located on the southern side of the valley between San Lorenzo de Tarapacá and Huarasiña (see fig. 2; Villalobos 1979; Brown \& Craig 1994; Gavira 2005; Mukerjee 2008). ${ }^{4,5}$ This work was carried out by indigenous and mestizo laborers drawn from the settlements of Tarapacá and Sibaya who had been assigned to mine owners by the Spanish Crown through the mit'a system (Mukerjee 2008).

The Quebrada de Tarapacá clearly served during the later Colonial Period as a source of labor for mining and refining operations and a place where both small and large-scale silver processing took place. Ethnohistoric documents are silent as to whether a similar relationship existed between the valley and the Huantajaya mines under the Inka empire and into the early Colonial Period. As argued below, archaeological data suggests that silver refining using the technique of scorification was indeed carried out on a small scale in and around the site of Tarapacá Viejo during the Late Horizon and early Colonial periods.

\section{MATERIALS AND METHODS}

The materials analyzed in this study derive from excavations at Tarapacá Viejo and a full-coverage pedestrian survey of the lower portion of the Quebrada de Tarapacá between Tilivilca and Pachica, an area of approximately $18 \mathrm{~km}^{2}$ (Zori 2011). Tarapacá Viejo was one of the principle pre-Hispanic and historic sites in the lower valley, and was occupied continuously from at least the Late Formative (500 BC-500 AD) until it was abandoned in AD 1717 (Núñez, L. 1979; Núñez, P. 1984, 1992; Uribe et al. 2007; Zori 2011). The site underwent significant episodes of remodeling in the Late Horizon and/or early Colonial periods, and the upper layers of the site contain a mixture of late preHispanic and historic materials (Núñez, P. 1984; Zori 2011). Seven 1 × $2 \mathrm{~m}$ test units and one $1 \times 4.5 \mathrm{~m}$ trench

Table 1. All metallurgical materials from excavation and survey.

Tabla 1. Todos los materiales metalúrgicos recuperados en la excavación y el registro.

\begin{tabular}{|l|c|c|c|c|}
\hline & Excavation & $\begin{array}{c}\text { \# and } \% \text { Analyzed } \\
(\text { XRF })\end{array}$ & $\begin{array}{c}\text { Survey } \\
\text { and Analyzed } \\
(\text { XRF })\end{array}$ \\
\hline Furnace fragments & 49 & $49(100 \%)$ & 254 & $117(46.1 \%)$ \\
\hline Pieces of slag & 117 & $45(38.8 \%)$ & 133 & $62(46.6 \%)$ \\
\hline Slagged ceramics/crucibles & 14 & $14(100 \%)$ & 22 & $22(100 \%)$ \\
\hline Mold fragments & 9 & $9(100 \%)$ & 5 & $5(100 \%)$ \\
\hline Metal production debris & 22 & $22(100 \%)$ & 2 & $2(100 \%)$ \\
\hline Identified and unidentified metal objects & 10 & $10(100 \%)$ & 2 & $2(100 \%)$ \\
\hline
\end{tabular}


Table 2. Materials related to silver production/refining from Tarapacá Viejo.

Tabla 2. Materiales relacionados con la producción/ refinación de plata en Tarapacá Viejo.

\begin{tabular}{|c|c|c|}
\hline AREA & SAMPLE NUMBER & MATERIAL \\
\hline 5 & L3C-A3-01 & Crucible fragment \\
\hline & L9-A1-01 & Crucible fragment \\
\hline 6 & L12E-C01 & Crucible fragment \\
\hline 8 & L1A-M01 & Lead metal \\
\hline & L6-A01 & Lead artifact \\
\hline & L11-M03 & Lead metal \\
\hline & L15B-C02-01 & Crucible fragment \\
\hline & L17A-C2-01 & Crucible fragment \\
\hline
\end{tabular}

were excavated to sterile at Tarapacá Viejo, sampling $10 \%$ of the rooms at the site (fig. 5). These excavations yielded hundreds of pieces of unsmelted copper ore, as well as materials related to the production of metals at the site, including buayra furnace fragments, slag, crucible fragments, casting molds, drips of metal and other production debris, and finished metal artifacts (Table 1; Zori 2011).

Metallurgical materials were also recovered from 26 distinct smelting sites identified in a full-coverage pedestrian survey of the lower valley (Zori 2011). These consist of variable quantities of clay-walled huayra fragments with slag on their interior faces, along with unsmelted ore, loose slag, slagged or vitrified ceramics, crucible fragments, and unburned charcoal fuel. The smelting sites are located on the western edges of the hills that line the quebrada, positioned to take advantage of the winds that blow west-east after midmorning. ${ }^{6}$ A small number of mold fragments, metal production debris, and metal artifacts were recovered from surface collections at habitational sites identified in the survey as well.

All of the slagged ceramics, crucibles, mold fragments, metal objects and metal production debris and a sub-sample of the furnace fragments and slag from both survey and excavation were subjected to X-ray fluorescence analysis (XRF; see Table 1) using a Bruker Keymaster Portable XRF unit with rhodium anodes. All samples were mechanically cleaned using a brush and then subjected to 200 seconds of $1.35-2.50 \mu \mathrm{A}$ of radiation using a $40 \mathrm{kV}$ X-ray tube. Tables of X-ray emission lines were used to determine the major, minor, and trace elements in each sample.

Materials related to silver production included furnace fragments, loose slag, slagged ceramics, and crucible fragments with high levels of lead and variable
Table 3. Materials related to silver production/refining from survey.

Tabla 3. Materiales relacionados con la producción/ refinación de plata del registro.

\begin{tabular}{|c|c|c|}
\hline SITE & SAMPLE NUMBER & MATERIAL \\
\hline \multirow[t]{3}{*}{ TR4000 } & L2-SL01* & Slag \\
\hline & L2-SLO2* & Slag \\
\hline & L3-FF01* & Furnace fragment \\
\hline \multirow[t]{2}{*}{ TR4003 } & L2-FF01 & Furnace fragment \\
\hline & L2-FF02 & Furnace fragment \\
\hline \multirow[t]{16}{*}{ TR4005 } & L1-A01-02* & Crucible fragment \\
\hline & L1-A01-03 & Crucible fragment \\
\hline & L2-FF01 & Furnace fragment \\
\hline & L2-FF02 & Furnace fragment \\
\hline & L1-A01-04 & Crucible fragment \\
\hline & L1-A01-05 & Crucible fragment \\
\hline & L1-A01-06 & Crucible fragment \\
\hline & L1-2007 & Crucible fragment \\
\hline & L1-ISD & Crucible fragment \\
\hline & L1-INL1 & Crucible fragment \\
\hline & L1-INL2 & Crucible fragment \\
\hline & L1-INL3 & Crucible fragment \\
\hline & L1-INL4* & Crucible fragment \\
\hline & L1-INL5 & Crucible fragment \\
\hline & L3-A01* & Crucible fragment \\
\hline & T1L-02 & Crucible fragment \\
\hline \multirow[t]{2}{*}{ TR4010 } & L1-A1 & Crucible fragment \\
\hline & L2-FF01 & Furnace fragment \\
\hline \multirow[t]{5}{*}{ TR4011 } & L1-FF01 & Furnace fragment \\
\hline & L1-FF05 & Furnace fragment \\
\hline & L1-FF13 & Furnace fragment \\
\hline & L2-FF01 & Furnace fragment \\
\hline & TR $051049.001^{* *}$ & Furnace fragment \\
\hline TR4016 & TR $051051.00^{* * *}$ & Furnace fragment \\
\hline \multirow[t]{2}{*}{ TR4034 } & L2-FF01 & Furnace fragment \\
\hline & L2-A01-02 & Slagged ceramic \\
\hline \multirow[t]{3}{*}{ TR4119 } & FF01 & Furnace fragment \\
\hline & FF05 & Furnace fragment \\
\hline & TR05 1054.006 *** & Furnace fragment \\
\hline \multirow[t]{4}{*}{ TR1024 } & TR 05 1024. 001 *** & Slag \\
\hline & TR 05 1024. 002*** & Slag \\
\hline & TR 05 1024. $003^{\text {**** }}$ & Slag \\
\hline & A1-L2-M01 & Lead metal \\
\hline TR1065 & TR05 1065.001 & Slag \\
\hline
\end{tabular}

* Analyzed using SEM/EMPA by Dr. Peter Tropper (2010 Ms)

**: Analyzed using XRF by Dr. David Scott (2005 Ms) 


\section{TARAPACÁ VIEJO}

\section{Excavated by TVAP in 2006 and 2007}

Excavated by P. Núñez and colleagues in 1970s
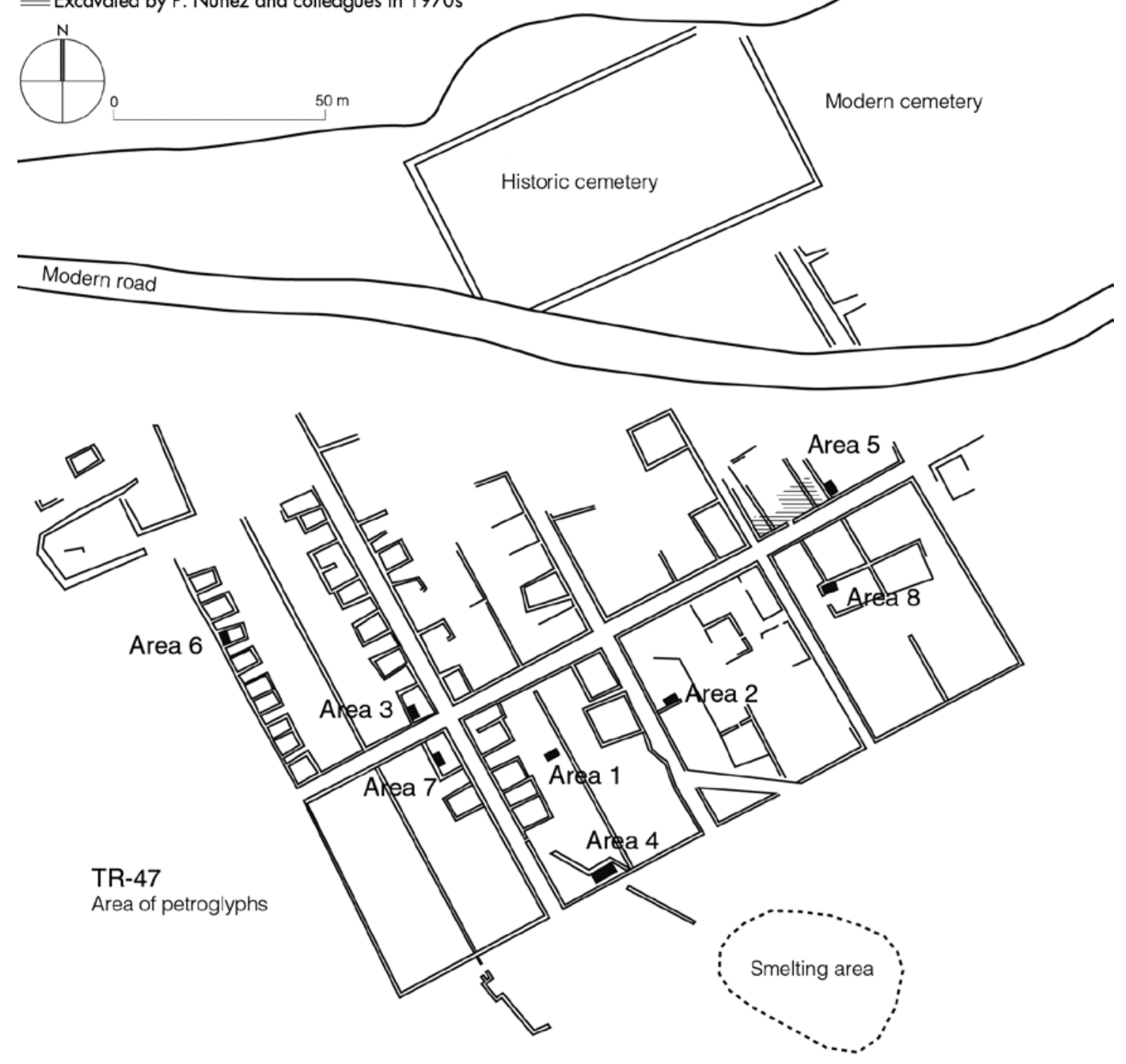

Figure 5. Architectural map of Tarapacá Viejo (adapted from map by Barnard 2008).

Figura 5. Plano de Tarapacá Viejo (adaptado del mapa realizado por Barnard 2008).

quantities of silver and other base metals (Tables 2 and 3). A subsample of these artifacts was subjected to further testing using polarized light microscopy (PLM), scanning electron microscopy (SEM), and electron microprobe analysis (EMPA). The elemental analyses were carried out at the Institute of Mineralogy and Petrography of the University of Innsbruck, Austria, using a JEOL JXA 8100 SUPERPROBE with five WDS detectors and a Thermo Noran EDS system. To cover the chemical composition of sulfides, sulfosalts, and metals, a first analytical routine was designed to examine the elements $\mathrm{S}$, $\mathrm{Cu} \mathrm{Fe}, \mathrm{Zn}, \mathrm{Hg}$, Mn, Mo, Cd, Ni, Pb, Co, Au, Ag, Ge, In, As, Sb, Bi, Se, Sn, and $\mathrm{Te}$, with 50-second peak and 40-second background counting times. A second routine focused on the silicate minerals, analyzing the elements $\mathrm{O}, \mathrm{S}, \mathrm{Si}, \mathrm{Mg}, \mathrm{Fe}, \mathrm{Mn}$, Cr, Ca, K, Na, Ba, Sr, Al, Ti, Ba, P, Zn, Cl, F, Sb, Cd, As, $\mathrm{Pb}, \mathrm{Ag}, \mathrm{Cu}$, and $\mathrm{Ni}$. Counting times were 20 seconds for the peak and 10 seconds for the background. The acceleration voltage was $15 \mathrm{KV}$ and the beam current $10 \mathrm{nA}$ for both analytical routines. 


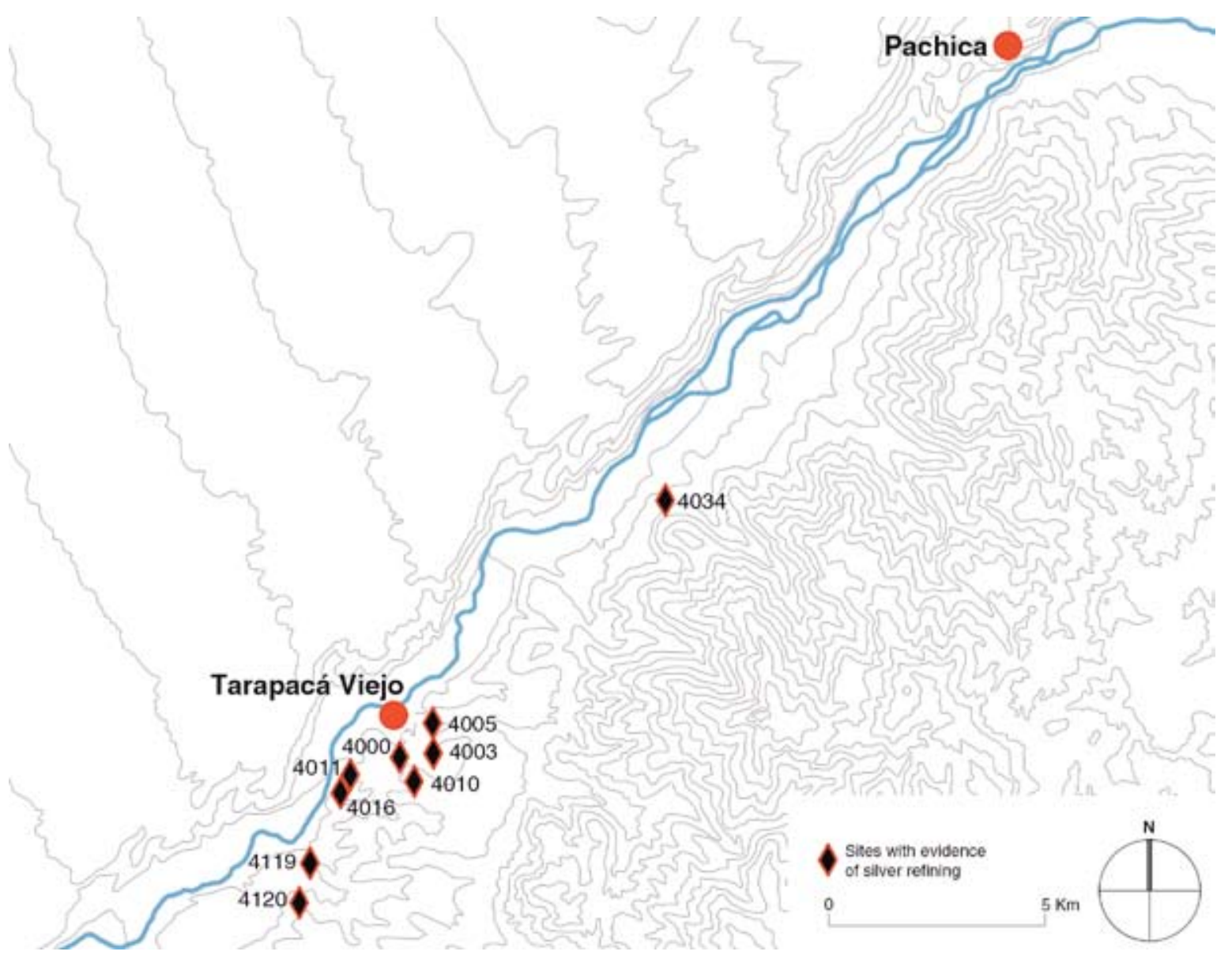

Figure 6. Smelting sites with evidence of silver production.

Figura 6. Sitios de fundición con evidencias de producción de plata.

\section{ARCHAEOLOGICAL EVIDENCE OF SILVER PRODUCTION IN THE QUEBRADA DE TARAPACÁ}

Evidence suggestive of several different stages in the production of silver was found in the excavations at Tarapacá Viejo and at ten smelting sites in the Quebrada de Tarapacá, all but one of which are located in relatively close proximity to the administrative center (fig. 6). These stages include the smelting of lead and/or lead-silver bullion and the scorification of lead-silver bullion in open ceramic vessels.

Although XRF analysis indicates that the majority of the clay huayra fragments recovered in the Quebrada de Tarapacá survey were from furnaces used to smelt copper, a small fraction (9 out of 117 , or $7.7 \%$ of the fragments tested) displayed elevated levels of lead in comparison with copper or other metals. ${ }^{7}$ Multiple XRF scans were performed to confirm that the high lead levels were found across the entire scorified internal face of the furnace fragments. One furnace fragment (sample TR4000-L3-FF01) from site TR4000 was selected for more in-depth metallurgical testing using SEMEPMA analysis, which confirmed the presence of lead in the slag lining the interior (fig. 7; Tropper 2009 Ms). It is unclear whether the high levels of lead in these furnaces is due to the addition of lead metal, lead ore, or litharge to silver-bearing ore to produce lead-silver bullion or if the furnaces were used for smelting pure lead, similar to what has been observed ethnographically (Van Buren \& Mills 2005; Cohen et al. 2008). This lead would have then been used to collect silver in smelts of polymetallic ores or in later purification stages. The scarcity of finished lead artifacts in the valley suggests that any lead produced using huayra furnaces was used for other purposes.

Site TR4000, located immediately to the east of Tarapacá Viejo, additionally yielded several pieces of 

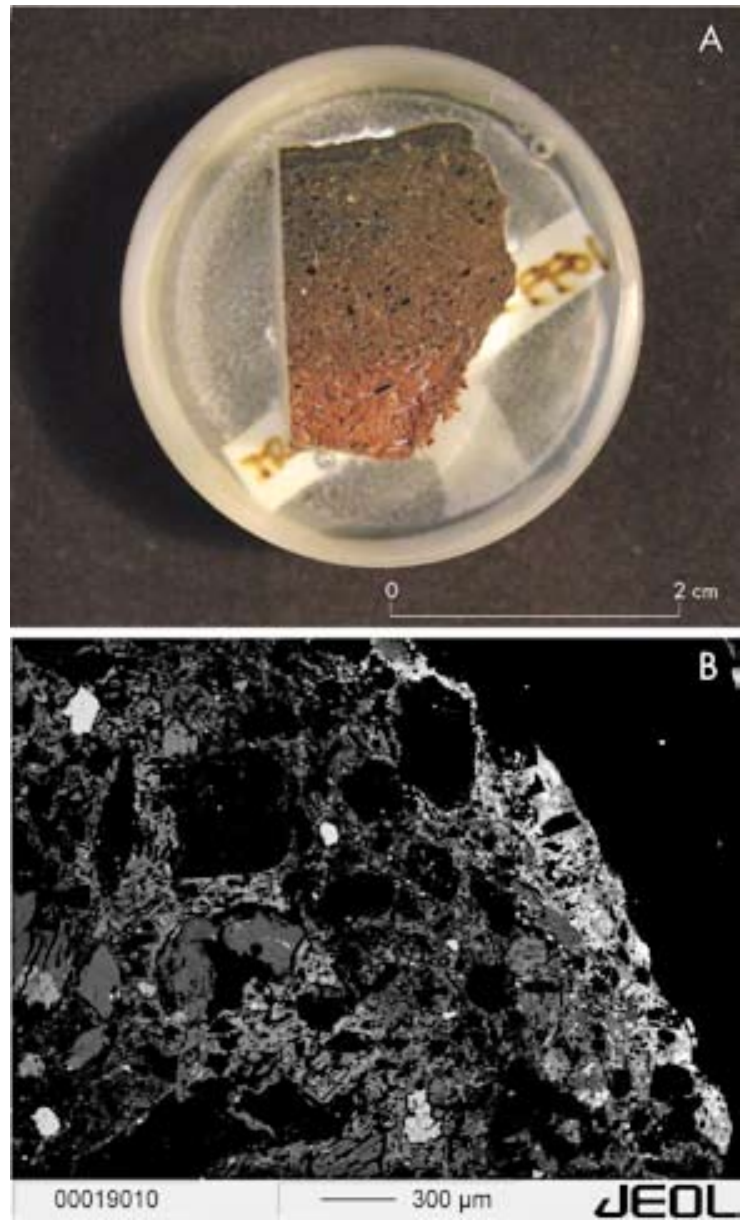

Figure 7. A) Sample TR4000-L3-FF01 mounted (photo by C. Zori); B) lead-bearing slag (light areas; photo by P. Tropper).

Figura 7. A) Muestra TR4000-L3-FFO1 montada (foto: C. Zori); B) escoria plomífera (áreas claras; foto: P. Tropper).

loose slag with high levels of lead. Slag sample TR4000L2-SL01 is composed of a lead-bearing silicate glass matrix with droplets of metal in which copper (with up to $2 \mathrm{wt} \% \mathrm{Fe}$ ) and iron (with up to $8 \mathrm{wt} \% \mathrm{Cu}$ ) occur intergrown with lead (with 3wt\% Cu; Tropper 2009 Ms; see Table 4 and figs. 8a-c). Although not subjected to SEM-EMPA, another sample of slag from TR4000 (TR4000-L3-SL01) also contained numerous prills in which copper and lead are intergrown, perhaps with iron (fig. 9). One of two areas of lead sampled with the microprobe (sample 4000-L2-SLO1 Pb-17) had a relatively high percentage weight of sulfur (almost $10 \mathrm{wt} \% \mathrm{~S}$; see Table 4), suggesting the formation of $\mathrm{PbS}$ and hence matte within the slag.

The second slag sample from TR4000, sample TR4000-L2-SL02, is also comprised of lead-bearing silicate glass and contains a number of lead prills (figs. 10a, b).
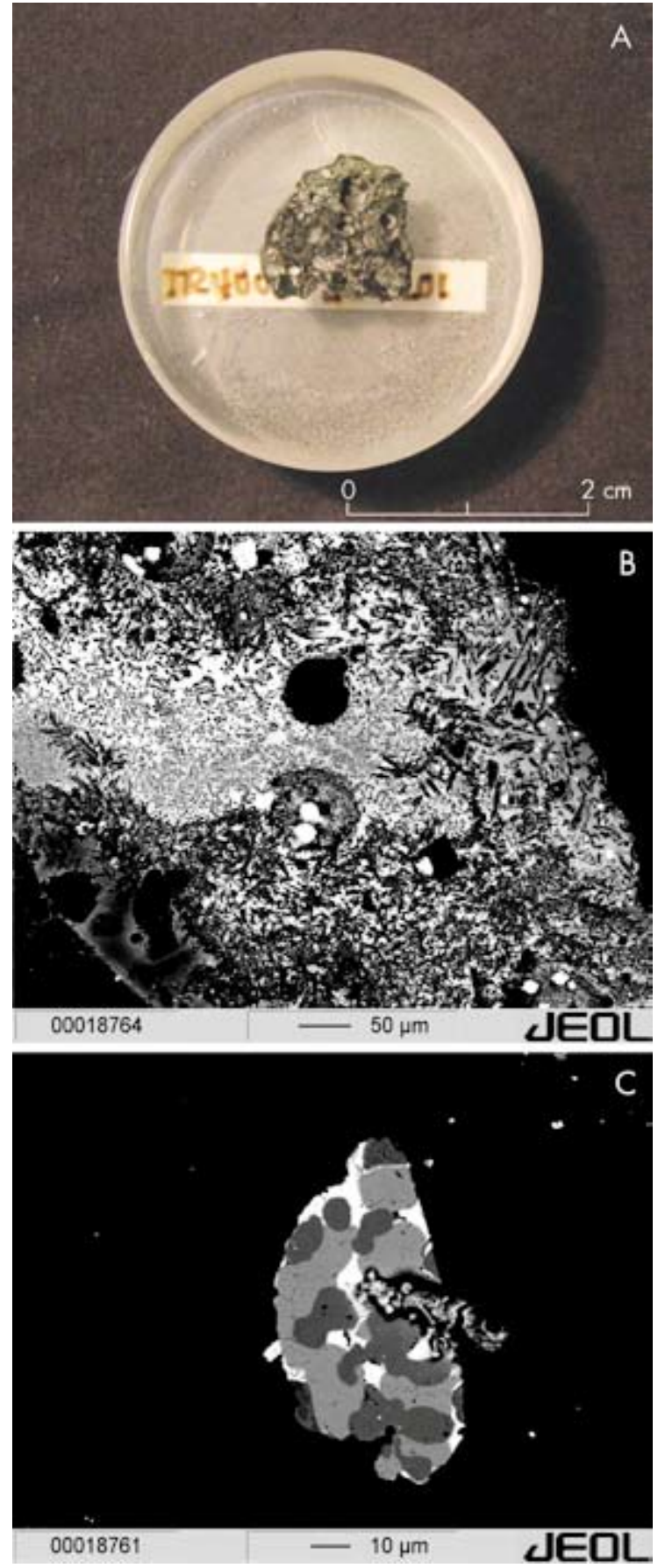

Figure 8. A) Sample TR4000-L2-SL01 mounted (photo by C. Zori); B) lead-rich slag with droplets of lead metal; C) prill in which copper (light gray), iron (dark gray) and lead (white) are intergrown (photos $\mathrm{B}$ and $\mathrm{C}$ by P. Tropper).

Figura 8. A) Muestra TR400O-L2-SLO1 montada (foto: C. Zori); B) escoria con abundante plomo con gotitas de plomo metálico; C) pepita con cobre (gris claro), fierro (gris oscuro) y plomo (blanco) intercrecidos (fotos B y C por P. Tropper). 


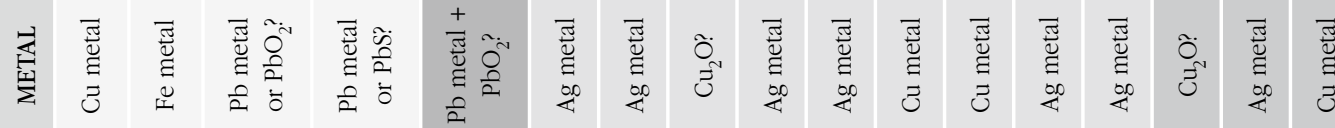

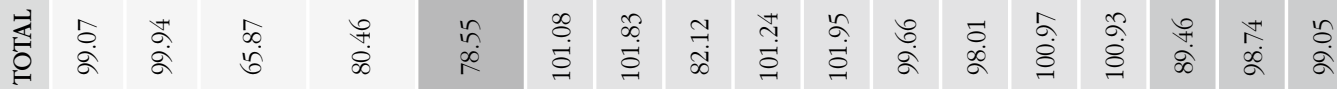

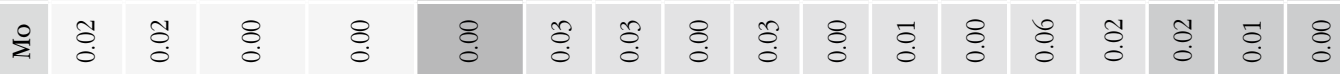
^

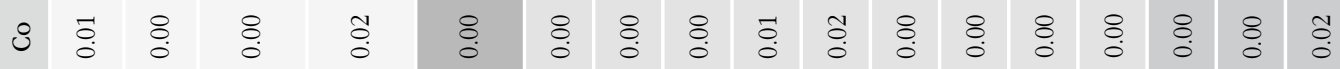
ज

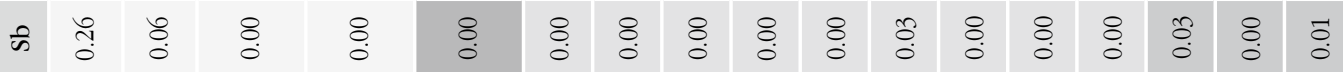

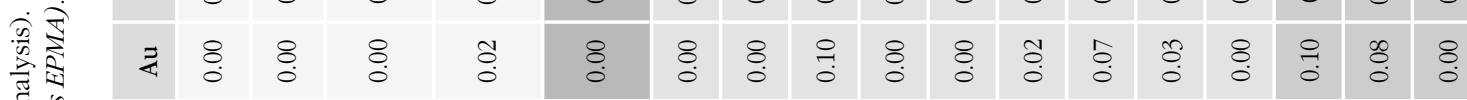

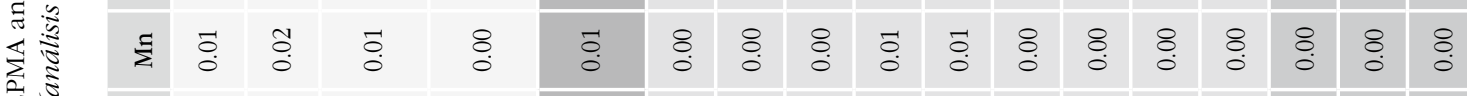

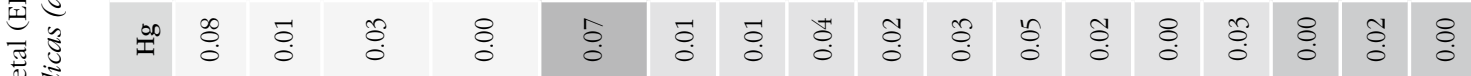
范密 剀

: $\frac{\overline{2}}{2}$

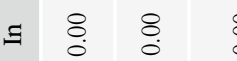

च

$\sqrt{3}$

i $8: 8+\infty$

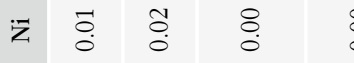

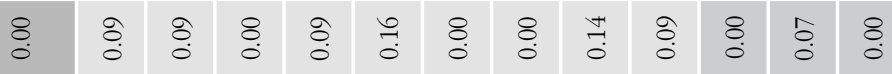

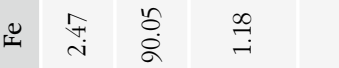

का ปี กู่ กี

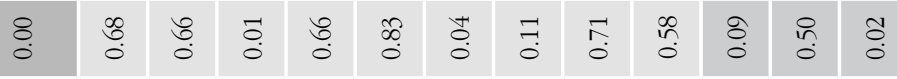
远

पั口

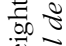

胥

8 :

苞

苟 8

$\forall \dot{4}$

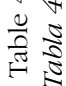

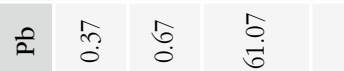

ऽ

ป

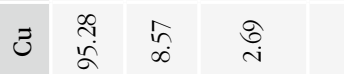

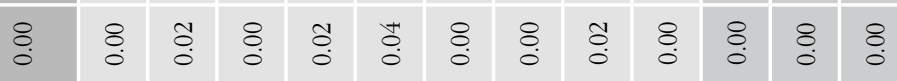

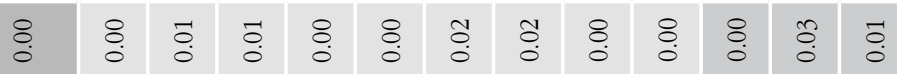

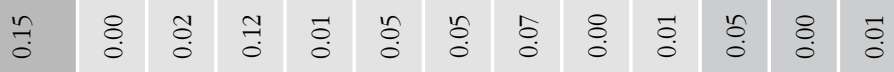

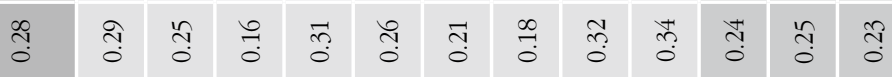

से

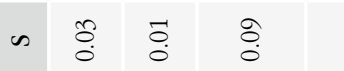

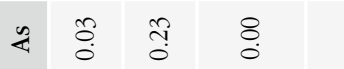

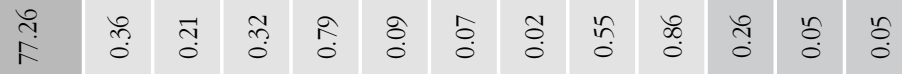

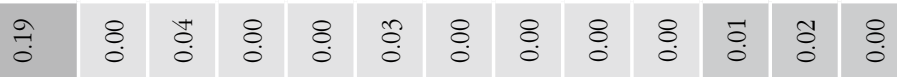

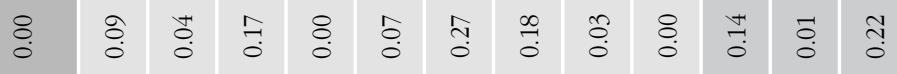

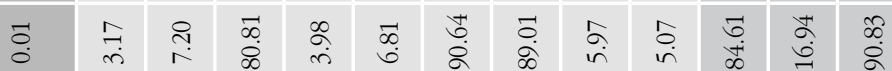

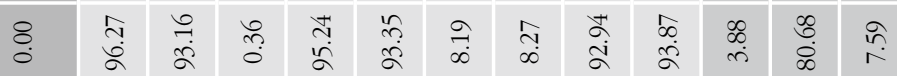

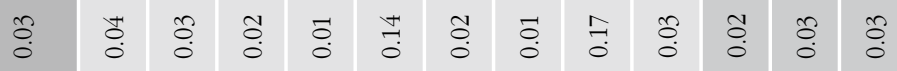

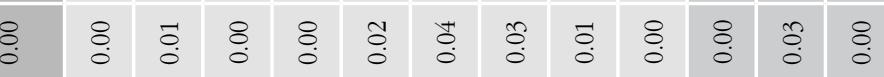

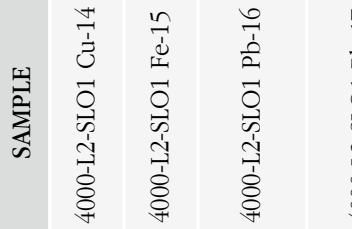

\begin{tabular}{|c|c|c|c|c|c|c|c|c|c|c|}
\hline 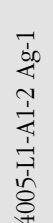 & 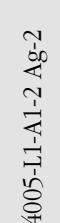 & 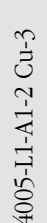 & 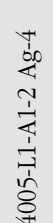 & 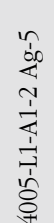 & 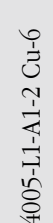 & 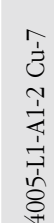 & 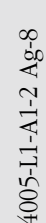 & 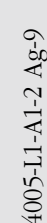 & & \\
\hline
\end{tabular}




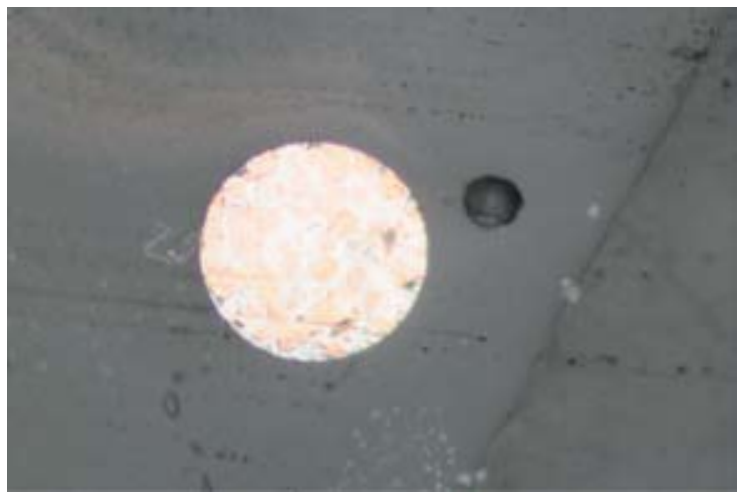

Figure 9. Sample TR4000-L3-SL01: prill with copper and lead intergrown (photo by C. Zori).

Figura 9. Muestra TR4000-L3-SLO1: pepita con cobre y plomo intercrecidos (foto: C. Zori).
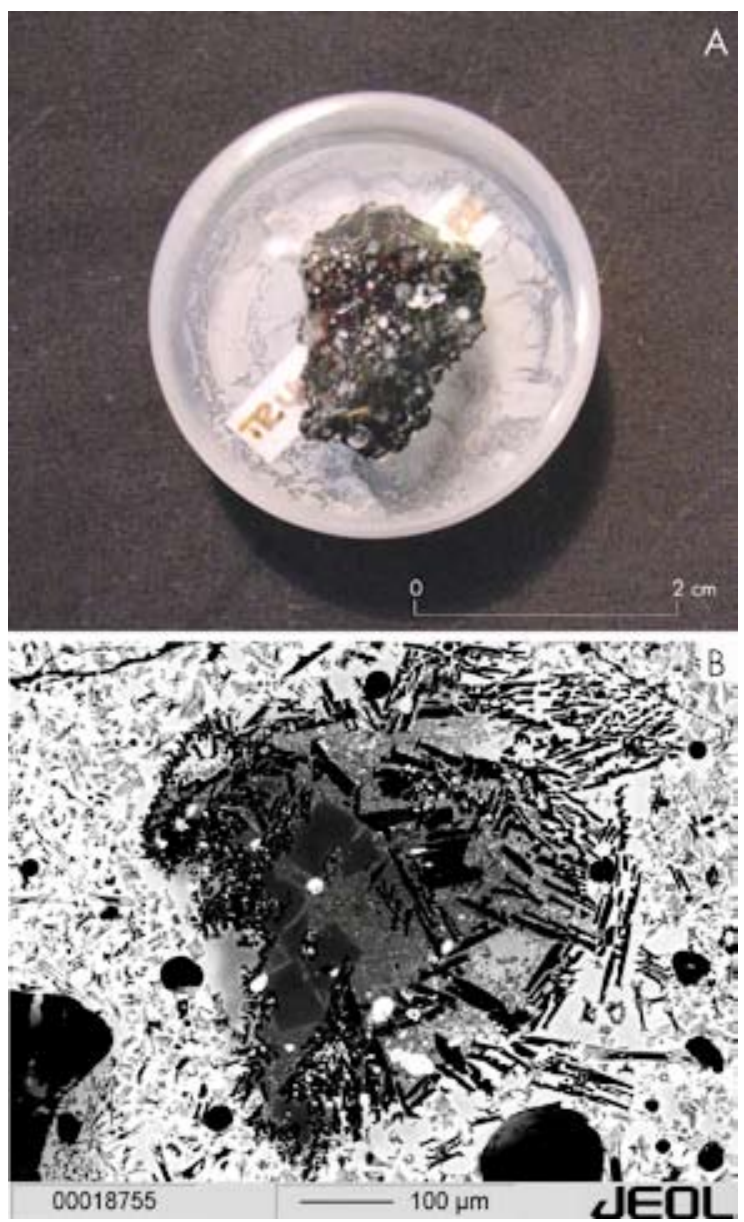

Figure 10. A) Sample TR4000-L2-SL02 mounted (photo by C. Zori); B) wollastonite quench crystals in bright Pb-bearing glass (photo by P. Tropper).

Figura 10. A) Muestra TR400O-L2-SLO2 montada (foto: C. Zori); B) cristales revenidos de wollastonita en vidrio brillante con plomo (foto: P. Tropper).
Testing of one prill revealed that there was little intergrowth between lead and copper or other metals in this particular case, possibly because of the high temperatures reached by this sample. The prill consisted of almost pure lead metal with a small quantity of lead dioxide (Table 4).

The high-lead slag samples from TR4000 may derive from the smelting of lead or lead-silver bullion in the buayra furnaces, or may be indicative of other activities such as scorification (see e. g. sample 1003 in Schultze et al. 2009). The absence of droplets of silver metal in either of the slags suggests that if they were from smelting, the furnaces were not used for producing lead-silver bullion but rather pure lead metal. The lack of silver in the slag also contrasts with analyses of several crucibles from site TR4005 (see below) that were used for refining lead-silver bullion, which contain silver prills. This difference suggests that the loose slags from TR4000 may indeed have been from the production of pure metallic lead (compare with Cohen et al. 2008).

Excavations at Tarapacá Viejo yielded examples of pure lead metal, including two amorphously shaped pieces that may have been used as metallic lead stock in either smelting or scorification procedures. A third object is a sheet of lead that has been cut into a roughly circular shape and then folded in half. It is not clear whether this was a piece of stock lead as well.

The scorification stage of silver production is evidenced by numerous fragments of open ceramic vessels with dark gray slag on their interiors, recovered from both excavations and survey (Table 2). XRF analysis of the slagged ceramics from Tarapacá Viejo demonstrated that they contain elevated levels of lead and traces of silver and accessory base metals, including copper. This is indicative of the elimination of lead and other metal impurities from the original lead-silver bullion through the formation of lead silicate slag. Some of the metallurgical materials in Area 8 were found in close physical proximity to a hearth area with deep ash deposits (fig. 11), raising the possibility that it was used for the scorification process.

Additional testing was performed on three fragments from different ceramic vessels recovered at the site of TR4005, a smelting site located on a hilltop approximately $1.5 \mathrm{~km}$ east of Tarapacá Viejo (see figs. 6 and 16). Preliminary XRF testing demonstrated that the dark gray slag on the interiors of these vessels had high levels of lead. Sample TR4005-L3-A1 derived from a fragment of a bowl-shaped vessel whose exterior was lightly burnished and covered in a red slip, suggestive of the Local Inka ceramic style and dating the vessel to the Late Horizon. Although none of the prills were large enough 
TARAPACÁ VIEJO, 2007 season

Area 8

Profile of western wall

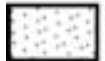

Surface laver of windblown sand and small organic debris (Surface and Locus 1 and 2 \}

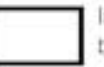

nterdigitated sand and botanicais (Locus 3)

Voose, dark brown, lots $x^{*} v^{*} v^{2}$ of organic (Locus 5)

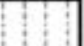

Loose, light brown with camelid guano. organio materials (Locus 6

Compact, dark brown layer. possible floor (Locus 8)

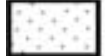

ight brown layer of compacted camelid dung (Locus 7)

Pog Sandy. greyish material with ash probable plastering of root (Locus 10)

Laver of sticks, vegetable fiber rcpe, and organics, probable collapsed root (Locus 9)

ight brown layer with high artifact content (Locus 11)

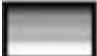

Stratified depcsit of ash and cartorn; hearth (Locus 12A)

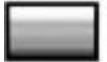

Stratified depcsit of ash and cartoon; hearth (Locus 12B)

A $\hat{A}$ A Concentration of maize husks, ANA A Slalks, and cobs (Locus 14)

Semi-compact layer with rocks and gravel, organic malerials, darkened by hoat exposure (Locus 16)

P. Layer of jumbled rocks and large o.g organic matorials (Locus 17 )

Compact layer, possible floot. sealing the trench of pit (Locus 19

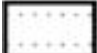

Jumbled rocks and large organic matorials, abundant cotton, tilling a trench or pit (Locus 20A-E)

F:s: Thin, brown and sandy layor at touttom of trench or pit (Locus 21)

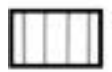

Sterile

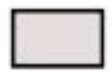

Rock

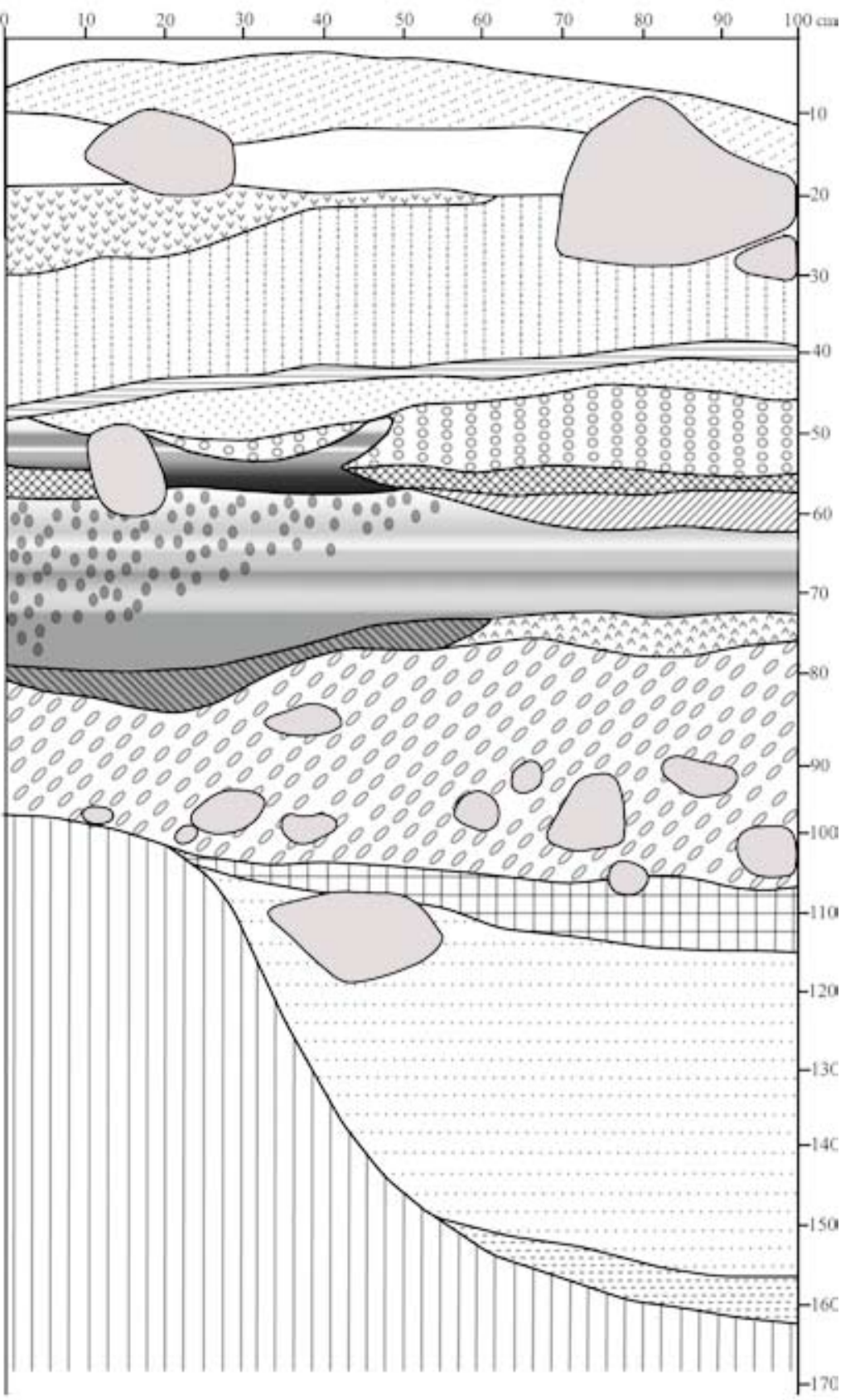

Figure 11. Profile from Area 8, showing deep ash deposits of hearth area.

Figura 11. Perfil del Área 8, mostrando depósitos profundos de cenizas en el sector del fogón. 

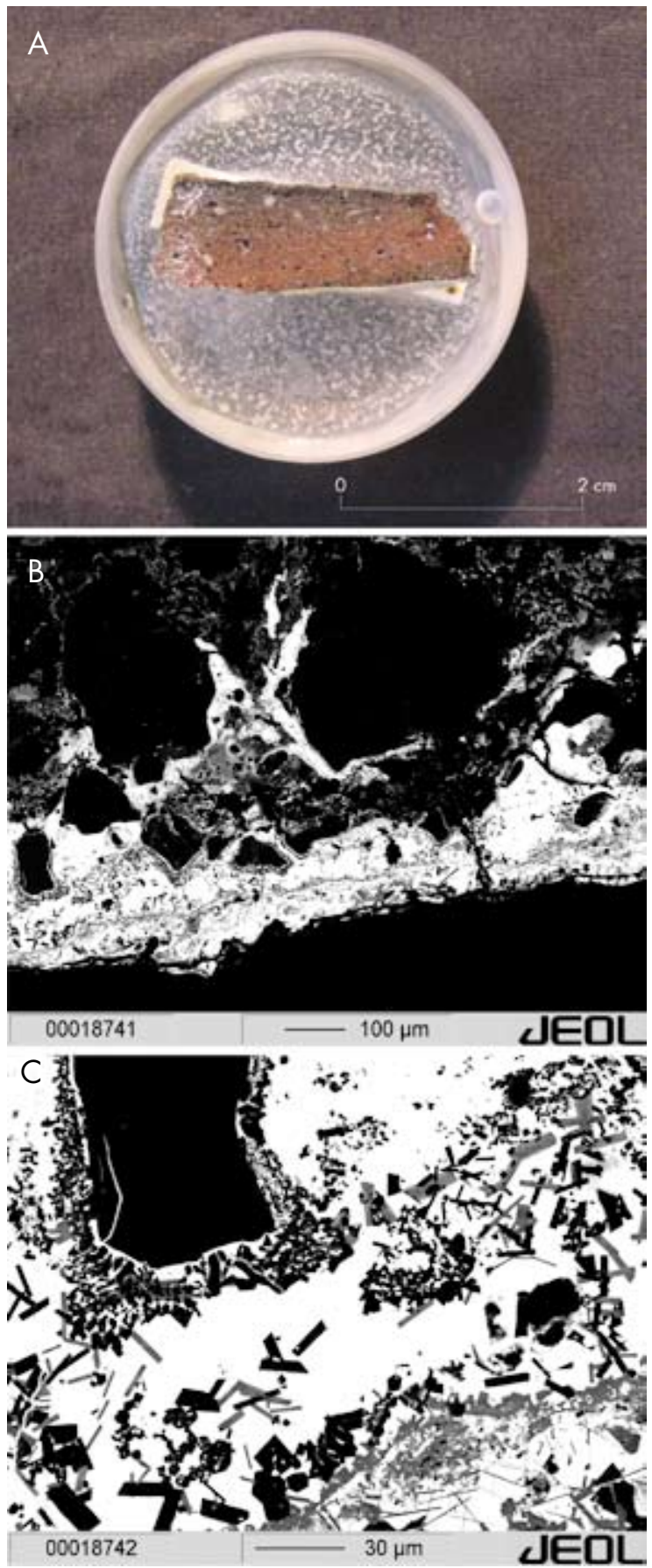

Figure 12. A) Sample TR4005-L3-A01 mounted (photo by C. Zori); B) bright lead-bearing glass; C) kalsilite (black) and melilite (grey) quench crystals in a Pb-Si glass of up to $75 \mathrm{wt} \% \mathrm{PbO}$ (photos B and $\mathrm{C}$ by $\mathrm{P}$. Tropper).

Figura 12. A) Muestra TR4005-L3-A01 montada (foto: C. Zori); $B$ ) vidrio brillante con plomo; C) kalsilita (negro) y melilita (gris), cristales revenidos en vidrio de $\mathrm{Pb}$-Si con hasta $75 \% \mathrm{PbO}$ (fotos $\mathrm{B}$ y C por P. Tropper). to be tested using the electron microprobe, SEM analysis of sample TR4005-L3-A1 shows the strong presence of lead in the dark gray silicate slag on the interior of the bowl-shaped vessel (figs. 12a, b). Quench crystals of kalsilite and melilite were found together with alamosite $\left(\mathrm{PbSiO}_{3}\right)$ in the Pb-Si glass of the slag (fig. 12c), indicating that the slag reached temperatures necessary to become fully molten. The glassy slag of this sample contained up to $52 \mathrm{wt} \%$ lead oxide (PbO), or litharge, which may have also been removed from the scorification vessel by skimming in the purification of the bullion (Lechtman 1976). XRF analysis of this crucible did not indicate the presence of silver in the slag.

A second crucible fragment from Locus 1 was also tested using SEM-EMPA. Sample TR4005-L1-INL4 derives from a Local Inka style bowl-shaped vessel with a diameter

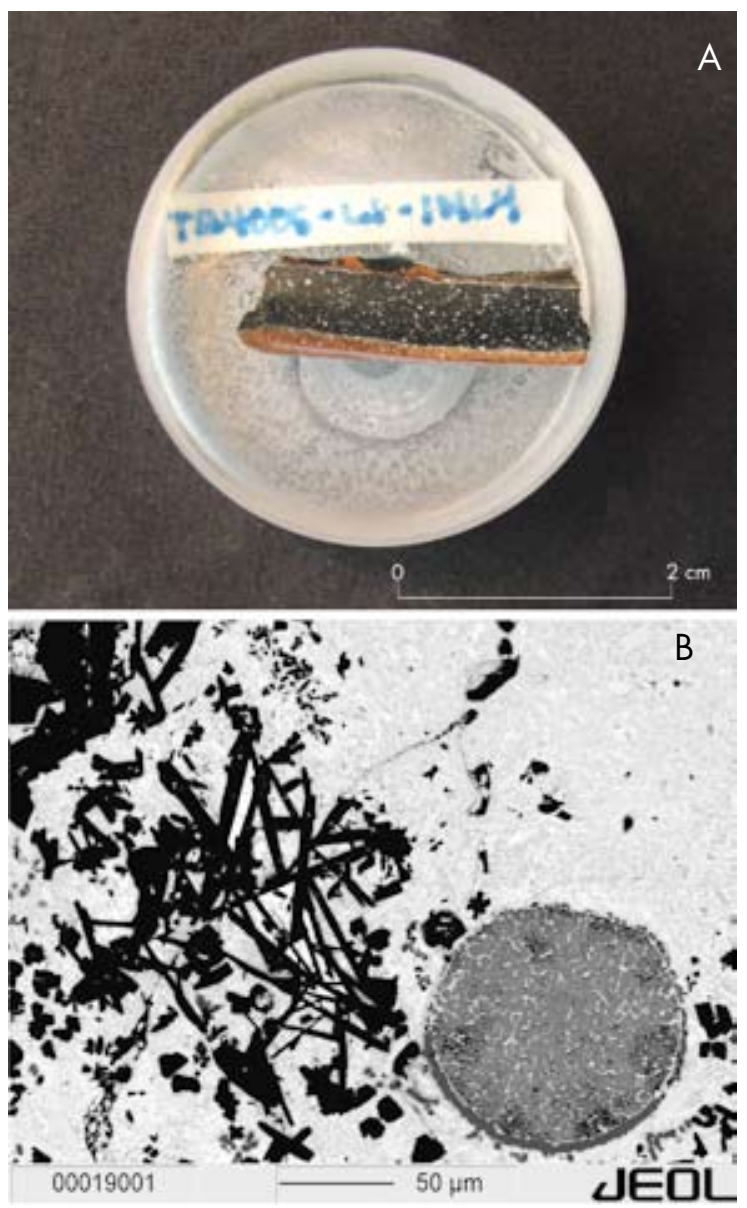

Figure 13. A) Sample TR4005-L1-INL4 mounted (photo by C. Zori); B) droplet of copper (grey, $8 \mathrm{wt} \% \mathrm{Ag}$ ) and silver (white, $17 \mathrm{wt} \% \mathrm{Cu}$ ) in lead-silica glass (light grey) and black quench crystals (kalsilite; photo by P. Tropper)

Figura 13. A) Muestra TR4005-L1-INL4 montada (foto: C. Zori); B) gotita de cobre (gris, $8 \%$ Ag) y plata (blanco, $17 \% \mathrm{Cu}$ ) en vidrio de plomo y sílice (gris claro) y cristales revenidos negros (kalsilita: foto: P. Tropper). 
somewhat larger than that of the preceding example. The interior of this vessel is coated with a dark grey lead silicate slag containing at least one prill in which copper (with $4 \mathrm{wt} \% \mathrm{Ag}$ ) occurs intergrown with silver (with 7.5 to $17 \mathrm{wt} \% \mathrm{Cu}$; see Table 4 and figs. 13a, b). The occurrence of some copper oxides $\left(\mathrm{Cu}_{2} \mathrm{O}\right.$; Table 4$)$ in the lead silicate slag suggests that it served to collect and remove base metals present in the original ores and is consistent with the interpretation that the reactions took place in the oxidizing environment necessary for scorification. The presence of quench crystals, including kalsilite, melilite, and clinopyroxene, in addition to the presence of relicts of plagioclase and quartz adjacent to them, suggest that the slag on the interior of this vessel had reached temperatures necessary to be almost completely molten.
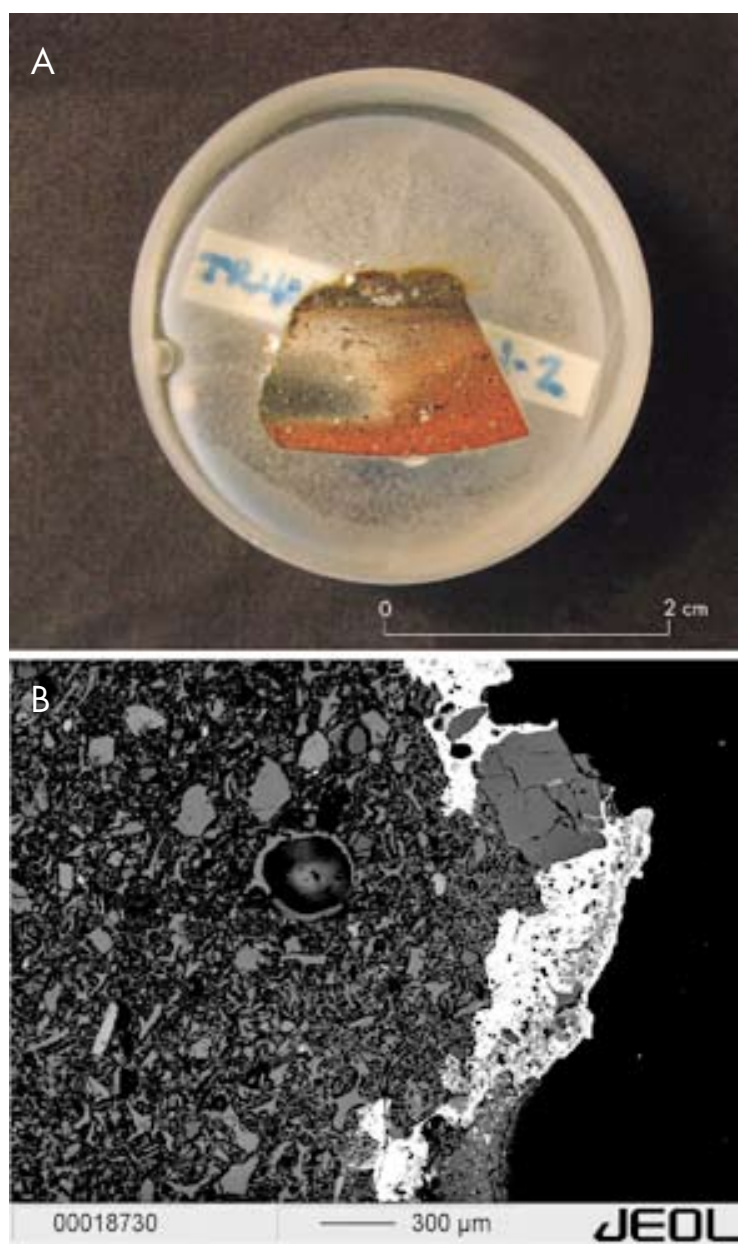

Figure 14. A) Sample TR4005-L1-A01-02 mounted (photo by C. Zori); B) bright lead-bearing glass with quench crystals (photo by P. Tropper).

Figura 14. A) Muestra TR4005-L1-A01-02 montada (foto: C. Zori); B) vidrio brillante plomífero con cristales revenidos (foto: P. Tropper).
Similar to the preceding two samples, crucible fragment TR4005-L1-A01-02 was originally part of a Local Inka style bowl. XRF analyses of the dark gray slag on the vessel interior showed very high levels of silver and lead and lower quantities of copper. SEM-EMPA confirmed that it was comprised of a silicate glass with strong lead contamination containing a metal prill in which copper (with $8 \mathrm{wt} \% \mathrm{Ag}$ ) is intergrown with silver (with up to $7 \mathrm{wt} \% \mathrm{Cu}$; figs. $14 \mathrm{a}$, b). Figure 15 depicts a particularly large droplet of silver metal, containing 4-6wt\% Cu. As was observed with sample TR4005-L1INL4, the presence of $\mathrm{Cu}_{2} \mathrm{O}$ (see Table 4) is indicative of an oxidizing environment.

Colonial and ethnographic sources suggest that the purification of lead-silver bullion through scorification and cupellation usually took place in sheltered places, such as domestic hearths or smaller reverberatory furnaces in workshops (Garcilaso de la Vega 1941-1943 [1609]; Capoche 1959 [1585]; Van Buren \& Mills 2005: 17). These sites are usually located near, but separate from, primary buayra smelting sites. The recovery of fragments of numerous vessels used for scorification from primary smelting sites located on open hilltops like TR4005 suggests the possibility that, at least in some cases, metallurgists in the Quebrada de Tarapacá used natural drafts to create the heat necessary for scorification. This may have been possible because the clay furnaces were portable, and could be positioned over the bowl or crucible where the scorification was taking place. Metallurgists in the valley may have placed a muffle, a domed or collar-like ceramic insert with a number of holes or perforations, over the scorification vessel to prevent direct contact between the lead-silver bullion

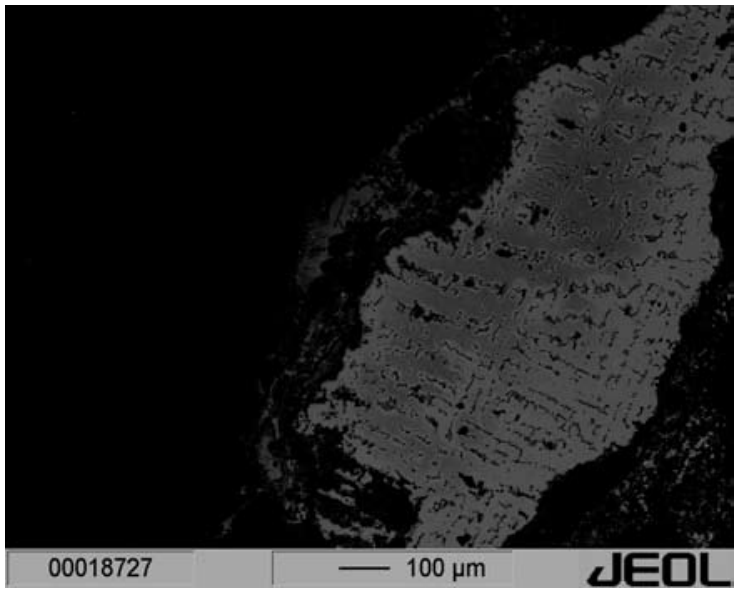

Figure 15. Prill of silver metal with 4-6wt\% Cu in sample TR4005L1-A01-02 (photo by P. Tropper).

Figura 15. Pepita de plata metálica con 4-6\% Cu, en la muestra TR4005-L1-A01-02 (foto: P. Tropper). 
and the charcoal fuel (see Barba 1923 [1640]: 199; Van Buren \& Mills 2005: 7-8).

Material evidence of cupellation, such as cupels, litharge, or small specialized hearths, was not identified in the excavations at Tarapacá Viejo or in the survey. Likewise, debris from the production of finished silver artifacts or the finished silver objects themselves were also absent. ${ }^{8}$ Although absence of evidence cannot be taken as conclusive evidence of absence, these data suggest that intermediate products of the silver production process, such as the silver-enriched bullion produced by scorification, were removed from the valley and the silver extracted elsewhere.

\section{DATING THE ADOPTION OF SILVER PRODUCTION TECHNOLOGY}

Perhaps one of the most challenging aspects of unraveling the complexities of silver production in the Quebrada de Tarapacá is establishing the date of the metallurgical materials from survey and excavation. There are three primary challenges. First, the majority of the smelting sites in the valley were continually used from the Late Intermediate Period through the Colonial Period. The deflated nature of these wind-exposed sites means that vertical stratigraphy is effectively non-existent, making it difficult to identify change over time. Second, copper production was carried out at all of the smelting sites identified in the survey: there were no sites in which silver production occurred exclusively. The methods used to date the smelting sites-a combination of surface ceramics, radiocarbon dating of unburned charcoal fuel, and spatial relationships with surrounding sites-thus provide an approximation of when metallurgical activities were carried out, rather than being unequivocally associated with silver production specifically. Third, dating of the excavated metallurgical materials from Tarapacá Viejo is problematic because many of the upper strata contain a mixture of materials from both the Late Horizon and early Colonial periods due to significant remodeling of the site in the late prehistoric and/or early historic periods.

There are, however, several lines of evidence consistent with the interpretation that the technique of silver purification using lead was adopted by the metallurgists of the Quebrada de Tarapacá during the Late Horizon. Excavation data document strong spatial associations between artifacts related to silver production and Inka materials at Tarapacá Viejo. Specifically, Area 5 and Area 8 (see fig. 5) contained all of the crucible fragments with high lead levels, as well the majority of the pure lead metal possibly destined for use in the smelting or cupellation processes. These two excavation units are located in the area of Tarapacá Viejo that has the greatest concentration of Inka-style artifacts.

Metallurgical activities carried out at the smelting sites with lead/silver production also date to the Late Horizon. One or more radiocarbon dates obtained from sites TR4000, TR4005, TR4010, and TR4011 fall within the Late Horizon, although the ranges for the dates frequently extend into the historic period (Graph 1 and Table 5). Radiocarbon dates were not obtained from the other six sites with possible evidence of silver production. The spatial distribution of ceramics recovered in systematic surface collection at the site of TR4005, which yielded the greatest number of crucibles used in scorification, indicates that the Inka occupation of the site focused almost exclusively on the smelting area, circumstantially linking silver production with the Late Horizon occupation of the site (fig. 16). This is supported by a calibrated radiocarbon date of $\mathrm{AD}$ 1404-1485 obtained from charcoal collected in the vicinity of the greatest concentration of high-lead crucible fragments. Historical ceramics are absent from the ten smelting sites with evidence of silver production, with the exception of a single sherd from a wheel-thrown vessel recovered at TR4005 and a number of glazed Colonial Period sherds from Locus 2 of TR4011. These data are consistent with the interpretation that silver production began in the Late Horizon and continued into the Colonial Period.

Of the crucibles recovered in excavation and survey for which the ceramic style could be determined, almost all were in use during the late Late Intermediate Period and the Late Horizon (see Uribe et al. 2007). The most common ceramic vessels used for scorification in the Quebrada de Tarapacá are bowls of the Local Inka style. Given that metallurgists in the valley appear to have used ceramic bowls or bowl fragments not specifically designed for metal production, it is likely that they would have chosen vessels readily available at the time. The prevalence of Local Inka bowls in the silver production assemblage thus suggests that this was when the process was first used. There are also a small number of fragments from vessels with shapes distinct from both the Late Intermediate Period and the Late Horizon styles. These vessels may have been produced during the Colonial Period, supporting the interpretation that lead cupellation was practiced into the historic era, perhaps even after several techniques using mercury amalgamation were introduced to the valley. 


\section{Calibrated date (calAD)}

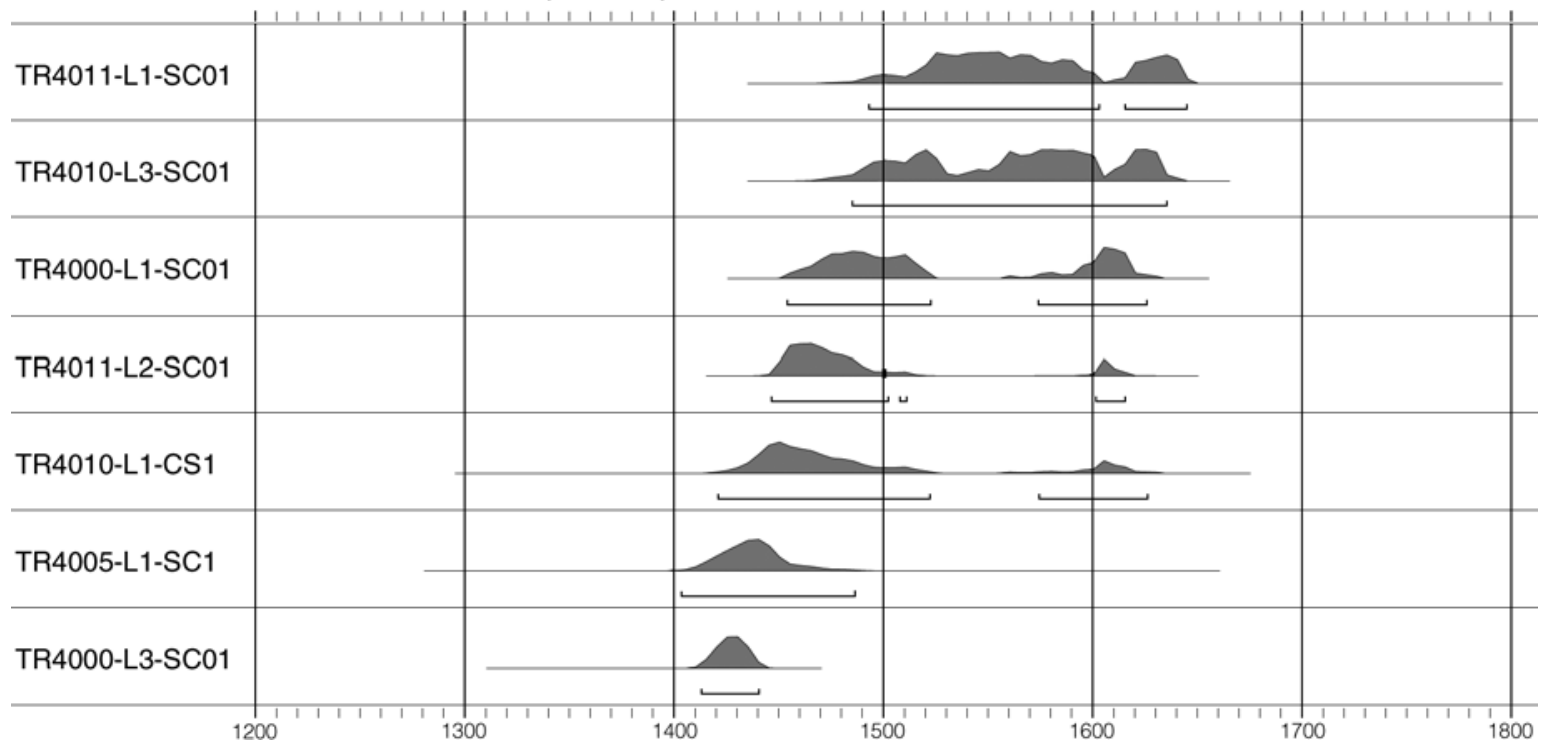

Graph 1. Radiocarbon dates for metallurgical sites with evidence of silver production (from Damiata $2009 \mathrm{Ms}$ ).

Gráfico 1. Fechas de radiocarbono para sitios metalúrgicos que muestran evidencias de producción de plata (tomado de Damiata 2009 Ms).

Table 5. Radiocarbon dates from metallurgical sites with evidence of silver production (from Damiata $2009 \mathrm{Ms}$ ). Tabla 5. Fechas de radiocarbono de sitios metalúrgicos que muestran evidencias de producción de plata (tomado de Damiata 2009 Ms).

\begin{tabular}{|c|c|c|c|}
\hline SAMPLE & FACILITY AND SAMPLE NUMBER & $\begin{array}{l}\text { RADIOCARBON AGE } \\
\text { (BP) }\end{array}$ & $\begin{array}{c}2 \sigma \text { CALIBRATED } \\
\text { RADIOCARBON AGE }\end{array}$ \\
\hline TR4011-L1-SC01 & $\begin{array}{l}\text { University of California, Irvine AMS } \\
\text { Laboratory; } 58822\end{array}$ & $315 \pm 15$ & AD $1493-1645$ \\
\hline TR4010-L3-SC01 & $\begin{array}{l}\text { University of California, Irvine AMS } \\
\text { Laboratory; } 58821\end{array}$ & $335 \pm 15$ & AD $1485-1635$ \\
\hline TR4000-L1-SC01 & $\begin{array}{l}\text { University of California, Irvine AMS } \\
\text { Laboratory; } 58817\end{array}$ & $365 \pm 15$ & AD $1454-1625$ \\
\hline TR4011-L2-SC01 & $\begin{array}{l}\text { University of California, Irvine AMS } \\
\text { Laboratory; } 58823\end{array}$ & $390 \pm 15$ & AD $1446-1615$ \\
\hline TR4010-L1-CS01 & $\begin{array}{c}\text { NSF - Arizona Accelerator Mass } \\
\text { Spectrometry (AMS) Laboratory; } \\
\text { AA82252 }\end{array}$ & $420 \pm 37$ & AD 1421-1625 \\
\hline TR4005-L1-SC1 & $\begin{array}{c}\text { NSF - Arizona Accelerator Mass } \\
\text { Spectrometry (AMS) Laboratory; } \\
\text { AA82249 }\end{array}$ & $465 \pm 37$ & AD 1404-1485 \\
\hline TR4000-L3-CS01 & $\begin{array}{l}\text { University of California, Irvine AMS } \\
\text { Laboratory; } 58818\end{array}$ & $495 \pm 15$ & AD $1413-1440$ \\
\hline
\end{tabular}




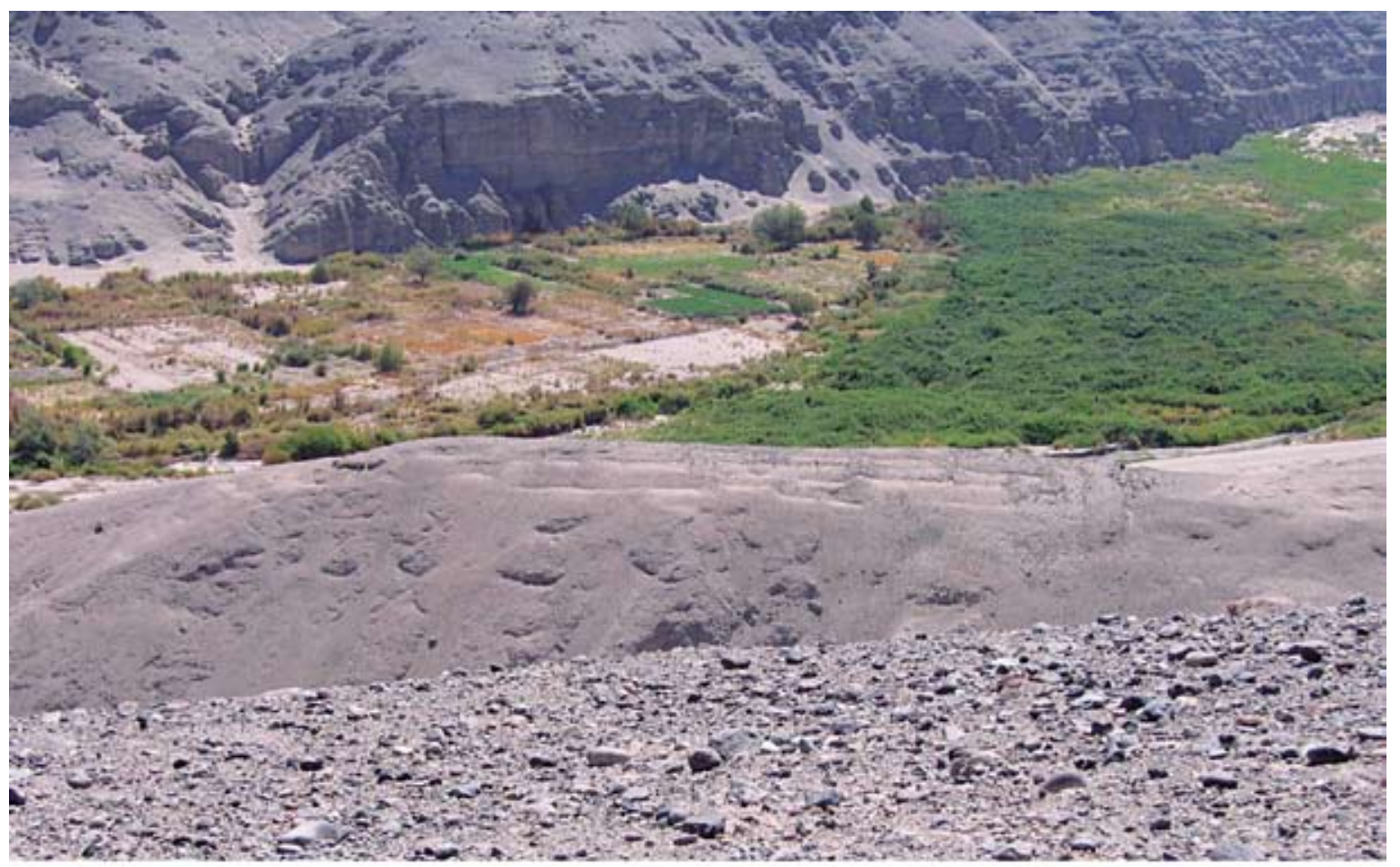

\section{TR4005}

Quantities of Late Horizon

Sherds per Collection Unit
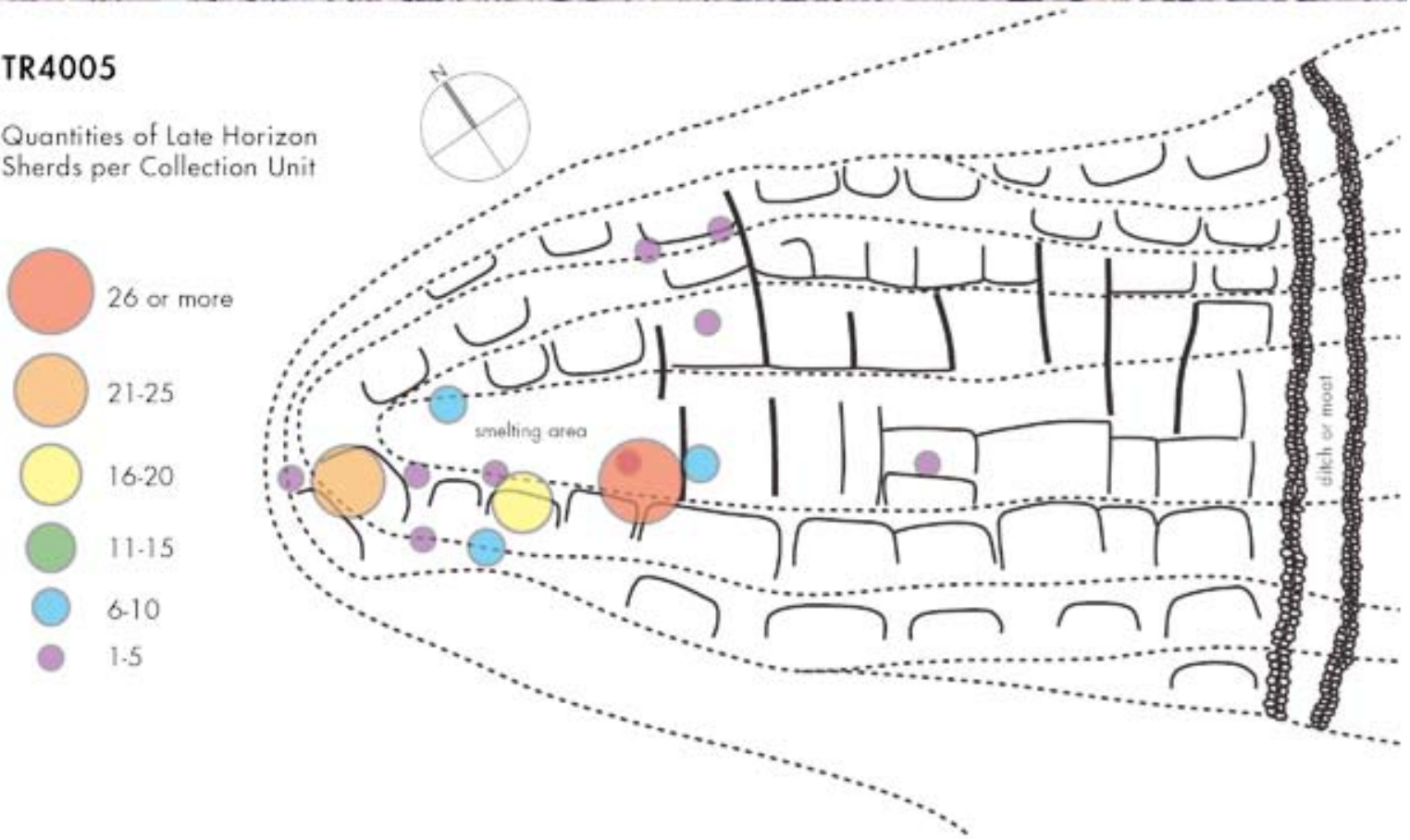

Figure 16. Site TR4005 and distribution of Inka ceramics from systematic surface collection, showing concentration of Inka ceramics in the smelting/silver production area (photo and map by C. Zori).

Figura 16. Sitio TR4005 y distribución de cerámica inkaica resultando de la recolección sistemática en la superficie, mostrando una concentración de cerámica inkaica en el área de fundición/producción de plata (foto y mapa por C. Zori). 


\section{DISCUSSION AND CONCLUSIONS}

Investigations in the Loa/Atacama region of northern Chile have demonstrated that the Inka extensively reorganized and expanded the extraction and beneficiation of copper in the region during the Late Horizon, using local mit'a laborers providing tribute to the state (Núñez, L. 1999; Salazar 2002, 2008; Adán \& Uribe 2005; Aldunate et al. 2008). Aridity and an absence of readily-available fuel for furnaces near the mines meant that the minerals were commonly transported to regional administrative centers, such as Catarpe, or specialized imperial smelting/metallurgical installations such as Viña del Cerro, for smelting (see fig. 1; Niemeyer et al. 1984, 1993; Lynch \& Núñez 1994; Castillo 1998). A similar scenario may have been true for silver-bearing ores in the Tarapacá region. Ethnohistoric sources indicate that the mines of Huantajaya were under the jurisdiction of the Inka, who may have drawn mit'a laborers from the Quebrada de Tarapacá and surrounding valleys to extract silver there. As observed in the Colonial Period, however, most silver smelting and refining was likely carried out where food, water, and fuel were more abundant, including the nearby Quebrada de Tarapacá.

Local metallurgists, probably also fulfilling their labor tribute to the Inka state, were responsible for the preliminary stages of silver refining in and around the administrative site of Tarapacá Viejo. The absence of evidence for the final cupellation stage or the manufacture of finished silver artifacts suggests that that the intermediate product-silver-enriched bullion-was collected by the state and removed from the valley for further processing under greater state supervision. An analogous situation has been observed at the imperial silver mining site of Porco, where there is good evidence of Inka-sponsored extraction, beneficiation, and smelting of silver but little indication of refining or the production of silver artifacts (Van Buren \& Presta 2010: 185). Ethnohistoric sources similarly indicate that ores and precious metals from the provinces were conveyed to Cuzco or other imperial centers, where they were transformed into sumptuary objects by skilled metallurgical specialists attached to the state (Cieza de León 1986 [1553]; LeVine 1987; Cobo 1990 [1653]: Ch. 15). Reduction of the amount of weight to be carried by refining the silver-bearing ores would have facilitated transport from the provinces.

The introduction of new European metallurgical technologies did not mean that indigenous techniques were completely abandoned (see also Cohen et al. 2008). The recovery of bowl-shaped vessels with lead silicate slags in styles that likely date to the Colonial Period suggests that the technique of scorification was used to purify silver in the historic era as well. In contrast to the process of mercury amalgamation, lead cupellation requires high-grade silver ores and produces silver on a relatively small scale. This would have been the ideal technique for the "artisanal refining" (Brown \& Craig 1994: 314) of silver-bearing ores from Huantajaya by indigenous and mestizo miners. Given the excavation and survey data discussed above, however, it is likely that this represents the continuation of an indigenous silver production tradition rather than the imposition or adoption of a new silver production technique via European contact.

ACKNOWLEDGEMENTS These investigations were conducted under the Tarapacá Valley Archaeological Project (TVAP) and Proyecto FONDECYT 1030923. Financial support was provided by the National Science Foundation and the Institute of American Cultures and the Department of Anthropology at the University of California, Los Angeles. Our sincerest gratitude to Mauricio Uribe, Ran Boytner, María Cecilia Lozada, David Scott, Ioanna Kakoulli, and students of UCLA and the Universidad de Chile for their help, as well as to Charles Stanish and three anonymous reviewers for their invaluable comments on earlier versions of this paper.

\section{NOTES}

${ }^{1}$ Quechua term for "place through which wind blows" (Van Buren \& Mills 2005: 4).

${ }^{2}$ Survey around Porco has identified small cupellation furnaces in association with indigenous households, although they appear to date to the historic period (Cohen et al. 2009).

3 The almost complete absence of Tiwanaku-style materials in survey or excavation (Zori 2011) suggests, however, that the technique of lead cupellation did not arrive in the Quebrada de Tarapacá through such a migration.

4 In the "patio process," powdered silver ores were spread over a large flat surface, combined with salt brine, a mixture of copper and/or iron pyrites, and mercury, and then left to react for a period of a few days to several weeks. The mercury collected the silver, forming a pasty amalgam that was then washed and finally roasted to recover both the silver and mercury. The silver was further refined in a small reverberatory furnace.

5 Also known as an ingenio, an azoguería was a mercury amalgamation facility where the patio process was used to extract silver.

${ }^{6}$ O'Brien writes that "commonly throughout the year, strong winds blow from the southwest from noon until the sun sets" (Hidalgo 2009: 32; our translation). He notes that the winds were strongest from late July/early August through March (Hidalgo 2009: 32). Wind speed measurements by the author taken in August and September average between $20-30 \mathrm{~km} / \mathrm{h}$, with a maximum measured velocity of $42.5 \mathrm{~km} / \mathrm{hr}$.

7 Because the portable XRF is used outside of a vacuum, it does not yield quantitative data. The amounts of lead can only be assessed in a relative fashion in comparison with the other metals present in the area sampled.

${ }^{8}$ An important difference between copper/bronze and silver production in the Quebrada de Tarapacá is that there is ample evidence for the manufacture of finished copper and bronze artifacts (Zori 2011). 


\section{REFERENCES}

AввотT, M. B. \& A. Wolfe, 2003. Intensive Pre-Incan Metallurgy Recorded by Lake Sediments from the Bolivian Andes. Science 301: 1893-1895.

ACOSTA, J. DE, 2002 [1590]. Natural and Moral History of the Indies. Durham, NC: Duke University Press.

ADÁn, L. \& M. Uribe, 2005. El dominio inca en la localidad de Caspana: Un acercamiento al pensamiento político andino (río Loa, norte de Chile). Estudios Atacameños 29: 41-66.

AlBóRNOZ, C., 1989 [1581/1585]. Instrucción para descubrir todas las guacas del Piru y sus camayos y haziendas. In Fábulas y mitos de los incas, H. Urbano \& P. Duviols, Eds., pp. 161-198. Madrid: Historia 16.

Aldunate, C.; V. Castro \& V. Varela, 2008. San Bartolo y Cobija: Testimonios de un modo de vida minero en las tierras altas y la costa de Atacama. Estudios Atacameños 35: 97-118.

Alonso Barba, A., 1923 [1640]. Arte de los metales. New York: John Wiley and Sons, Inc.

Bargalló, M., 1973. La "guira", horno de fundición del antiguo Perú: Estudio de las referencias de los cronistas. In Trabajos, artículos y apuntes, 1940-1972, sobre química, enseñanza, y metalurgia mexicana y de Hispanoamérica colonial, H. Mayagoitía, F. Villarreal \& J. Bolívar, Eds., pp. 426-435. Mexico: Morellos.

Berthelot, J., 1986. The Extraction of Precious Metals at the Time of the Inca. In Anthropological History of Andean Polities, J. Murra, N. Wachtel \& J. Revel, Eds., pp. 69-88. Cambridge: Cambridge University Press.

BOLlaERT, W., 1851. Observations on the Geography of Southern Peru, Including Survey of the Province of Tarapacá, and Route to Chile by the Coast of the Desert of Atacama. Journal of the Royal Geographical Society of London 21: 99-130.

Bouysse-Cassagne, T., 2005. Las minas del centro-sur andino, los cultos prehispánicos y los cultos cristianos. Bulletin de l'Institut Français d'Etudes Andines 34: 443-462.

2008. Minas del sol, del Inka, y de la gente. Potosí en el contexto de la minería prehispánica. In Mina y metalurgia en los Andes del Sur desde la época prebispánica hasta el siglo XVII, P. Cruz \& J. J. Vacher, Eds., pp. 303-348. Sucre: Institut de Recherche pour le Développement / Instituto Francés de Estudios Andinos.

Brown, K. \& A. Craig, 1994. Silver Mining at Huantajaya, Viceroyalty of Peru. In In Quest of Mineral Wealth: Aboriginal and Colonial Mining and Metallurgy in Spanish America, A. Craig \& R. West, Eds., pp. 303-327. Baton Rouge, LA: Department of Geography and Anthropology, Louisiana State University.

CAPOCHe, L., 1959 [1585]. Relación General de La Villa Imperial de Potosí. Biblioteca de Autores Españoles. Madrid: Atlas.

Castillo, G., 1998. Los períodos Intermedio Tardío y Tardío: desde la cultura Copiapó al dominio inca. In Culturas prehistóricas de Copiapó, H. Niemeyer, M. Cervellino \& G. Castillo, Eds., pp. 163-182. Santiago: Impresos Universitaria.

CASTRO, V., 1992. Nuevos registros de la presencia inca en la provincia de El Loa, Chile. Gaceta Arqueología Andina VI: 139-154

Checura, J., 1977. Funebria incaica en el Cerro Esmeralda. Estudios Arqueológicos 5: 125-141.

Cieza de León, P., 1986 [1553]. Crónica del Perú. Lima: Pontificia Universidad Católica del Perú, Fondo Editorial.

Сово, B., 1979 [1653]. History of the Inca empire: an account of the Indians' customs and their origin, together with a treatise on Inca legends, history, and social institutions. Austin: University of Texas Press.

1990 [1653]. Inca Religion and Customs. Austin: University of Texas Press.

Cohen, C.; T. Rehren \& M. VAn Buren, 2008. La huayrachina por dentro y por fuera: un estudio arqueometalúrgico de la tecnología de fundición de plomo en Porco-Potosí, Bolivia. In Mina y metalurgia en los Andes del Sur desde la época prebispánica hasta el siglo XVII, P. Cruz \& J. J. Vacher, pp. 29-56.
Sucre: Institut de Recherche pour le Développement / Instituto Francés de Estudios Andinos.

2009. An Archaeometallurgical Study of the Use of European Furnaces in Colonial Bolivian. Archaeometallurgy in Europe: Proceedings of the $2^{\text {nd }}$ International Conference, 17-21 June 2007, Aquileia, Italy, pp. 529-540, Associazione Italiana di Metallurgia, Milano.

Cooke, C. A.; M. B. AвbotT \& A. Wolfe, 2008. Late-Holocene atmospheric lead deposition in the Peruvian and Bolivian Andes. The Holocene 18 (2): 353-359

Cornejo, L., 1995. El Inka en la región del río Loa: Lo local y lo foráneo. Hombre y Desierto 9: 203-213.

Damiata, B., 2009 Ms. Results of AMS Dating and Carbon StableIsotope Analysis of Charcoal and Organic Samples, Tarapacá Valley Archaeological Project, Chile. Archaeological Progress Report.

Garcilaso de la Vega, I., 1941-1943 [1609]. Los Comentarios Reales de los Incas. Colección de Historiadores Clásicos del Perú, annotated by H. Urteaga. Vol. I-III. Lima: Imprenta y Librería Gil.

Gavira, M., 2005. Producción de Plata en el Mineral de San Agustín de Huantajaya (Chile), 1750-1804. Chungara 37: 37-57.

GonZÁlez, L. R., 2002. Heredarás el bronce: Incas y metalurgia en el sur del valle de Yocavil. Intersecciones en Antropología 3: 54-69.

Gordon, R. \& R. KNopf, 2007. Late horizon silver, copper and tin from Machu Picchu, Peru. Journal of Archaeological Science 34: 38-47.

Graffam, G.; M. Rivera \& A. Carevič, 1996. Ancient Metallurgy in the Atacama: Evidence for Copper Smelting during Chile's Early Ceramic Period. Latin American Antiquity 7: 101-113.

Hidalgo, J., 1985. Proyectos coloniales de riego del desierto: Azapa (cabildo de Arica, 1619); Pampa Iluga (O’Brien, 1765) y Tarapacá (Mendizábal, 1807). Chungara 14: 202-220.

2009. Civilización y fomento: La "Descripción de Tarapacá" de Antonio O'Brien, 1765. Chungara 41: 5-44.

Howe, E. G. \& U. Peterson, 1994. Silver and Lead in the Late Prehistory of the Mantaro Valley, Peru. In Archaeometry of Pre-Columbian Sites and Artifacts, D. A. Scott \& P. Meyers, Eds., pp. 183-197. Los Angeles: The Getty Conservation Institute.

Lechtman, H., 1976. A Metallurgical Site Survey in the Peruvian Andes. Journal of Field Archaeology 3 (1): 1-42.

LEVINE, T. Y., 1987. Inka Labor Service at the Regional Level: The Functional Reality. Ethnobistory 34 (1): 14-46.

LYNCH, T. \& L. NúÑEZ, 1994. Nuevas evidencias incas entre Kollahuasi y río Frío (I y II regiones del norte de Chile). Estudios Arqueológicos 11: 145-164.

Maksaev, V.; B. Townley, C. Palacios \& F. Camus, 2007. Metallic ore deposits. In The Geology of Chile, T. Moreno \& W. Gibbons, Eds., pp. 179-199. London: The Geological Society.

Mukerjee, A., 2008. La negociación de un compromiso: la mita de las minas de plata de San Agustín de Huantajaya, Tarapacá, Perú (1756-1766). Bulletin de l'Institut Français d'Etudes Andines 37: 217-225.

Niemeyer, H.; M. Cerveluino \& E. MuÑoz, 1984. Viña del Cerro: Metalurgia Inka en Copiapó, Chile. Gaceta Arqueología Andina 2: 6-7.

Niemeyer, H.; G. Castillo \& M. Cervellino, 1993. Estrategia del dominio Inca en el valle de Copiapó. In Actas del XII Congreso Nacional de Arqueología Chilena, Vol. 1, pp. 333371, Santiago.

Niemeyer, H. \& V. Schiappacasse, 1988. Patrones de asentamiento incaico en el Norte Grande de Chile. In La frontera del Estado inca, T. Dillehay \& P. Netherly, Eds., pp. 141-179. Oxford: BAR International Series.

NúÑEZ, L., 1979. Emergencia y desintegración de la sociedad tarapaqueña: Riqueza y pobreza en una quebrada del norte chileno. Atenea 439: 163-213.

1999. Valoración minero-metalúrgica circumpuneña: menas y mineros para el Inka rey. Estudios Atacameños 18: 177-221. 
NúÑEz, P., 1984. La antigua aldea de San Lorenzo de Tarapacá, Norte de Chile. Chungara 13: 53-65.

1992. Tarapacá Viejo: ¿Es el pueblo de indios de Lucas Martínez Vegazo? En Comunidades indígenas y su entorno, M. Muermann \& J. Muñoz, Eds., pp. 59-66. Santiago: Universidad de Santiago de Chile.

Оенм, V., 1984. Investigaciones sobre minería y metalurgia en el Perú prebispánico: una visión crítica actualizada. Bonn Seminar fur Volkerkunde, Universität Bonn.

Patterson, C., 1971. Native Copper, Silver and Gold Accessible to Early Metallurgists. American Antiquity 36: 286-321.

Petersen, G., 1970. Minería y metalurgia en el Antiguo Perú. Arqueológicas 12: 3-152.

Peele, R., 1893. A Primitive Smelting Furnace. School of Mines Quarterly 15: 8-10.

Pizarro, P., 1986 [1571]. Relación del descubrimiento y conquista de los Reinos del Perú. Lima: Pontificia Universidad Católica del Perú.

PlatT, T.; T. BOUYSSE-CASSAgNe \& O. Harris, 2006. Qaraqara-Charka. Mallku, Inka y Rey en la provincia de Charcas (siglos XV-XVII). Histórica antropológica de una confederación aymara. La Paz: Institut Français d'Etudes Andines.

Raffino, R.; R. Iturriza, A. IÁcona, A. Caparelli, D. Gobbo, V. Montes \& R. VÁsQuez, 1996. Quillay. Centro metalúrgico inka en el Noroeste argentino. Tawantinsuyu 2: 59-69.

SAlazAR, D., 2002. El complejo minero San José del Abra, II Región. Una aproximación a la arqueología de la minería. Memory for the degree of Magíster en Arqueología. Facultad de Ciencias Sociales, Universidad de Chile, Santiago.

2008. La producción minera en San Jose del Abra durante el Período Tardío Atacameño. Estudios Atacameños 36: 43-72.

Schultze, C. A.; C. Stanish, D. Scott, T. Rehren, S. Kuehner \& J. FeATHERS, 2009. Direct evidence of 1,900 years of indigenous silver production in the Lake Titicaca Basin of Southern Peru. Proceedings of the National Academy of Sciences 106 (41): 17280-17283.

SCoTt, D., 2005 Ms. Examination of the Metallurgical and Ceramic Products, Quebrada de Tarapacá, Chile. Archaeological Progress Report.
SöDERBERG, A., 2004. Metallurgic ceramics as a key to Viking Age workshop organization. Journal of Nordic Archaeological Science 14: 115-124.

Téreygeol, F. \& C. CASTRO, 2008. La metalurgia prehispánica de la plata en Potosí. In Mina y metalurgia en los Andes de Sur desde la época prehispánica hasta el siglo XVII, P. Cruz \& J. J. Vacher, pp. 11-28. Sucre: Institut de Recherche pour le Développement / Instituto Francés de Estudios Andinos.

Trelles, E., 1982. Lucas Martínez Vegazo: funcionamiento de una encomienda peruana inicial. Lima: Pontificia Universidad Católica del Perú, Fondo Editorial.

Tropper, P., 2009 Ms. Preliminary Results of SEM/EPMA Testing on Materials from the Quebrada de Tarapacá. Archaeological Progress Report.

Tylecote, R. F., 1964. Roman Lead Working in Britain. The British Journal for the History of Science 2 (1): 25-43.

Villalobos, S., 1979. La economía de un desierto: Tarapacá durante la Colonia. Santiago: Pontificia Universidad Católica de Chile.

Uribe, M., 1999-2000. La arqueología del Inka en Chile. Revista Chilena de Antropología 15: 63-97.

Uribe, M. \& C. Carrasco, 1999. Tiestos y piedras talladas de Caspana: La producción alfarera y lítica en el Período Tardío del Loa Superior. Estudios Atacameños 18: 55-71.

Uribe, M.; L. Sanhueza \& F. Bahamondes, 2007. La cerámica prehispánica tardía de Tarapacá, sus valles interiores y costa desértica, norte de Chile (ca. 900-1450 D.C.): Una propuesta tipológica y cronológica. Chungara 39 (2): 143-170.

VAn Buren, M. \& H. Mills, 2005. Huayrachinas and Tocochimbos: Traditional Smelting Technology of the Southern Andes. Latin American Antiquity 16 (1): 3-25.

Van Buren, M. \& A. Presta, 2010. The Organization of Inka Silver Production in Porco, Bolivia. In Distant Provinces in the Inka empire: Toward a Deeper Understanding of Inka Imperialism, M. Malpass \& S. Alconini, Eds., pp. 173-192. Iowa City: University of Iowa Press

Zori, C., 2011. Metals for the Inka: Craft Production and Empire in the Quebrada de Tarapacá, Northern Chile. Unpublished Doctoral Thesis, Department of Anthropology, University of California, Los Angeles. 
